\title{
ESTRUTURAS TERRITORIAIS DINÂMICAS E MUDANÇAS MODERNIZADORAS AO LONGO DE 70 ANOS EM MINAS GERAIS (1940 - 2010)
}

\author{
DYNAMIC TERRITORIAL STRUCTURES AND MODERNIZATION ALONG \\ 70 YEARS IN THE BRAZILIAN STATE OF MINAS GERAIS -(1940 - 2010)
}

\author{
ESTRUCTURAS DINÁMICAS TERRITORIALES Y MODERNIZACIÓN \\ A LO LARGO DE 70 AÑOS EN EL ESTADO BRASILEÑO DE \\ MINAS GERAIS (1940 - 2010)
}

\author{
Alfredo Costa \\ Doutorando em Geografia pelo Programa de Pós-Graduação em Geografia - IGC/UFMG e Professor \\ Assistente do Centro Universitário de Belo Horizonte (UNIBH) \\ Av. Pres. Antônio Carlos, 6627 - Pampulha, Belo Horizonte - MG, CEP 31270-901 \\ Tel. (+55 31) 3409-5000 \\ E-mail: alfredo.ufmg@yahoo.com.br
}

\section{RESUMO}

Este artigo busca evidenciar empiricamente que o Estado de Minas Gerais passou por importantes mudanças estruturais e modernizadoras entre 1940 e 2010, as quais foram capazes de mudar seu perfil produtivo e alterar o padrão distributivo da população. Para tanto, dados sobre população e produção referentes aos dois anos elencados foram analisados tendo em vista a comparação do seu comportamento nos municípios de maior relevância urbana nos seus respectivos anos de referência, ou seja, centralidades dinâmicas e altamente produtivas na configuração da rede urbana mineira, denominados aqui como "municípios-destaque", em relação aos demais municípios mineiros. Verificou-se que a Minas Gerais de 1940, de economia predominantemente rural e população desconcentrada, tornou-se outra em 2010, de forte economia urbanoindustrial, com maior concentração demográfica nas médias e grandes cidades.

Palavras-chave: Modernização, Reestruturação, Território, Minas Gerais.

\section{ABSTRACT}

This article aims to demonstrate empirically that the State of Minas Gerais (Brazil) presented important structural and modernizing transformations between 1940 and 2010. These changes were able to transform its production profile and its population distribution pattern. The empirical exercise consisted on comparing population and production data of the most urbanized municipalities with the data presented by the other municipalities in its years of reference. The main conclusions shows that the State of Minas Gerais had a predominantly rural economy and a decentralized population 
in 1940, and a strong urban-industrial economy with a relevant and growing network of medium and large cities in 2010.

Key-words: Modernization, Restructuration, Territory, Minas Gerais.

\section{RESUMEN}

Este artículo busca demostrar empíricamente que el Estado de Minas Gerais (Brasil) presentó importantes cambios estructurales y modernizadores entre 1940 y 2010 , que fueron capaces de cambiar su perfil de producción y el patrón de distribución de supoblación. En este sentido, se analizaron los datos sobre la población y la producción para los dos años mencionados con el fin de comparar su comportamiento en los municipios de mayor importancia urbana y económica en sus respectivos años de referencia, en relación com el resto de los municipios de el Estado. Se constató que el Estado de Minas Gerais en 1940 era de economía predominantemente rural y de población descentralizada, y se convirtió en otroen 2010, con una fuerte economía urbano-industrial y una mayor concentración de la población en ciudades medianas y grandes.

Palabras-clave: Modernización, Reestructuración, Territorio, Minas Gerais. 


\section{INTRODUÇÃO}

Este estudo aborda as reestruturações territoriais em Minas Gerais no período compreendido entre 1940 e 2010 sob a perspectivado urbano em mudança. A hipótese de que houve um processo de modernização e reestruturação econômica dos municípios mineiros sustenta-se nos significados da mudança do seu perfil produtivo, que em 1940 era prioritariamente baseado no setor primário, e em 2010 no setor secundário. Verifica-se em 1940 um cenário com mais nexos com o passado do que com o futuro, uma vez que, preservadas aquelas tendências, Minas Gerais deveria ser hoje um estado de base produtiva fundamentalmente rural, o que não se verifica. Acredita-se que com base nestes dois pontos no tempo - 1940 e 2010 - pode-se falar em reestruturação do território mineiro com base no processo de urbanização e na relação entre a produção agropecuária e industrial.

Para tanto, propõe-se aqui responder quatro questões fundamentais: I) O que são mudanças modernizadoras e mudanças estruturais no contexto de Minas Gerais?;II)Em que medida essas mudanças são verificadas nos municípios mineiros?; III) Por que é possível dizer que Minas Gerais teve modernização precoce em relação aos demais estados brasileiros?;eIV)É possível estabelecer laços entre concentração urbano-econômica e modernização em Minas Gerais?

Como pano de fundo, tem-se o estado de Minas Gerais como um caso exemplar em que determinados eventos macroestruturais de grande significação pontuaram sua história desde o século XVIII, e em larga medida denotaram em pioneirismo no processo de modernização urbana e sua reestruturação econômica. Um destes eventos macroestruturais - possivelmente o mais importante - diz respeito ao impulso que a mineração na então Capitania produziu no Brasil, de tal modo que a partir do século XVIII se reconhecesse como país. Essa mineração foi responsável pela estruturação de uma rede urbana importante que demarcou territorialmente o sudeste brasileirode modo expressivo, especialmente do ponto de vista de sua extensão geográfica a oeste. Como resultado, Minas viabiliza o Rio de Janeiro, que se tornarácapital imperial. Sem Minas, a capital muito provavelmente permaneceria em Salvador ${ }^{1}$.

Valle et al. (2014) sintetiza as fases de evolução da rede urbana brasileira da seguinte maneira: "No caso do Brasil a evolução da rede urbana, apesar de suas origens em meados do século XVII (no eixo Recife - Salvador, como resultado do desenvolvimento econômico gerado pela "indústria do açúcar"); século XVIII (nas Minas Gerais, como consequência dos movimentos de ascensão e queda da mineração) e século XIX (no eixo Rio-São Paulo, já como resultante da economia cafeeira); apresentou uma guinada em suas características a partir do segundo quartel dos anos 1950 com o esforço do presidente Juscelino Kubitscheck e seu Plano de Metas (50 anos em 5), a modernização industrial, o início da modernização agrícola, bem como os maciços investimentos na infraestrutura de transportes, com destaque para inserção de nova malha rodoviária, que acabou se transformando em um local prioritário para o surgimento de centros urbanos" (VALLE et al., 2014, p. 01). 
Além disso, a Minas Gerais do Século XVIII é uma centralidade interiorana que vai lançar tentáculos para Goiás, Mato Grosso, parte do vale do São Francisco, e para o Rio de Janeiro, tudo isso estruturado por caminhos que articulam uma rede urbana com duração efetiva de 100 anos (MATOS et al., 2006). É possível dizer que entre 1750 até meados de 1870-80 essa rede comanda a articulação territorial no Brasil. Entretanto, a partir de 1880 verifica-se outra perspectiva do ponto de vista da reestruturação:surgem as ferrovias e o início da hegemonia paulista. Reatualiza-se uma nova estruturação espacial, de fundo predominantemente urbano (NEGRI, 1996). No início da década de 1920, São Paulo ultrapassa o Rio de Janeiro (DINIZ, 1981; CANO, 1997; CANO, 2002; TAVARES, 2000), sendo que a partir deste momento ambos passam a competir em paralelo pela primazia econômico-produtiva do país, o primeiro por meio do maciço investimento no setor industrial, e o segundo por sediar a capital da República. Entre1950 e 60 a força de São Paulo passa a impactar definitivamente as reestruturações urbano-industriais do país.

Destarte, o objetivo a que se propõe alcançar aqui é a evidenciação empírica de que, considerando o período 1940-2010, é provável que se estivesse diante de duas Minas: uma Minas urbano-industrial de 2010 em que aspectos de uma pós-modernidade já estão demarcando as fisionomias territoriais de muitas cidades, ou seja, um cenário no qual a indústria já saiu das cidades e já produziu um terciário muito vigoroso, o que resultou em cidades com comércio e serviços de diversos tipos funcionando de uma maneira bastante intensa; outra Minas Gerais diz respeito àquela de 1940, na qual o que marcaria ainda fortemente o espaço mineiro seria a primazia da agropecuária, o que a situaria diante de um mundo agrário-rural, a despeito das tentativas de industrialização que ocorreram desde o século XIX (DINIZ, 1981). Ou seja, se em 2010 Minas Gerais é urbana e industrial com forte setor de serviços, em 1940 o Estado épredominantemente rural e agrário.

\title{
Modernização e reestruturação territorial: aspectos conceituais e nexos com a formação de Minas Gerais
}

Garcia (2000), em artigo sobre os mais recentes processos de modernização dos municípios mineiros, traça um rico panorama bibliográfico sobre as teorias de modernização, do qual decorre a seguinte síntese:

\begin{abstract}
Dentro do escopo das teorias de modernização, Inkeles e Smith [1981] explicitaram que osaspectos cabais de uma sociedade moderna incluem a educação de massa, a urbanização, a industrialização e meios rápidos de comunicação; Harvey [1989]apontou para os processos de produção e de consumo; Featherstone[1995] salientou a industrialização, a expansão da ciência e da tecnologia e a urbanização; e Inglehart[1997], a industrialização, urbanização, educação de massa, especialização ocupacional e desenvolvimento de meios de comunicação (GARCIA, 2000, p. 929).
\end{abstract}


O autor conclui que há duas dimensões analíticas no debate sobre modernização: a da industrialização, em que se destacam questões relacionadas à produção e ao consumo de bens e serviços, além da reprodução da força de trabalho; e da urbanização, em que pesam sua intensidade, a infraestrutura essencial à sua implementação e o desenvolvimento das telecomunicações. Espindola (2012) contribui para essa definição ao evidenciar que o conjunto de modificações modernizadoras (políticas, econômicas, sociais e culturais) são aquelas que marcam a instauração da sociedade urbano industrial no século XIX e nas primeiras décadas do século XX.

Dadas às devidas proporções, quando se verificam as cidades modernas e pré-modernas no Brasil, há uma modernidade precoce já assistida na Minas do ouro. Cidades como Ouro Preto, Mariana, São João Del Rey, Sabará e Diamantina experimentaram, já na primeira metade do século XVIII, fenômenos tipicamente urbanos jamais vistos no Brasil com tamanha intensidade ${ }^{2}$. A região viveu um forte adensamento populacional, diversificação das atividades produtivas, mobilidade social possibilitada por sucessivas descobertas de novas lavras, alto consumo, velocidade dos meios de comunicação, calçamento de vias e utilização das técnicas arquitetônicas mais modernas da época, entre outros (MATOS, 2011), fatos que, inclusive, ocorreram simultaneamente à primeira Revolução Industrial, importante marco da modernidade. No campo político e filosófico, não se pode deixar de mencionar a Inconfidência Mineira (1798), marco histórico que teve forte influência das revoluções francesa e americana, cujas premissas já apontariam como uma grande seta em direção ao futuro, pois já trazia os fundamentos da revolução política nacional.

Esta primazia mudou o foco das relações no território - anteriormente concentrado no nordeste brasileiro - e os meios pelos quais se estruturou foram fundamentais para a articulação de uma rede demográfica e financeira que perdura até os dias de hoje (MATOS, 2011). Possivelmente, sem a descoberta das jazidas de ouro e diamante - e as estruturações sociais que delas decorreram - a região sudeste brasileirademoraria mais tempo para se tornar a mais dinâmica da atualidade.

Todavia, a dinamização decorrente da exploração do ouro em Minas Gerais não foi suficiente para articular as redes mercantis brasileiras em nível nacional e, à medida que o ouro foi se escasseando, os laços mercantis fomentados por ele também se fragilizaram

\footnotetext{
2 Segundo Matos (2011), "perto da metade do século, Minas contava com a maior população e o maior número de assentamentos densos da Colônia. As atuais Ouro Preto, Mariana, Sabará, Serro, Diamantina, São João Del Rei, Tiradentes, Caeté, Pitangui abrigavam sobrados, palácios, igrejas e chafarizes, obras de arte, mas também cadeias e câmaras, vendas, albergues, prostíbulos e casebres. Violência e conflitos de toda ordem, marcas típicas de qualquer cidade dinâmica da época, somavam-se ao fato de que a mobilidade social era alta. Havia um número expressivo de brancos e mulatos livres e forros ao lado da "incessante" expansão da compra de escravos. A mestiçagem, a variedade étnica e os interesses da Coroa tanto motivavam disputas e ressentimentos quanto propiciava a multiplicação de meios de sobrevivência, atividades e ofícios inauditos” (MATOS, 2011, p. 47)
} 
(mas não se perderam) e implicaram em um processo de estagnação econômica que atravessou o século XIX (DULCI, 1999). Conforme assevera Negri (1996), ao final do século XIX, o Brasil passou a ser um país majoritariamente rural composto por economias regionais com escassas relações mercantis entre si, apesar das iniciativas industriais no território. Nesse momento imperava uma grande dependência dos países periféricos em relação aos países centrais industrializados, e até o último terço do século XIX o Brasil dependia diretamente do mercado internacional. Os"frágeis laços que uniam as regiões brasileiras confirmavam a característica dispersa da economia, que funcionava de forma semelhante aos enclaves exportadores sediados em regiões isoladas" (MATOS, 2014, p. 38). Essas economias regionais, apesar de fundamentarem a consolidação de uma expressiva base territorial, eram compostas por uma incipiente rede de localidades e enclaves semi-autárquicos.

A década de 1880 representa um marco na reversão desse cenário, quando um conjunto de profundas transformações econômicas no país - com mais significativo peso em São Paulo - consolidam o avanço do capitalismo no Brasil. Estas transformações elencadas por Negri (1996) envolvem:

- A substituição da mão-de-obra africana escravizada - em razão dos seus altos preços decorrentes do fim do escravismo - pela mão-de-obra europeia assalariada;

- A constituição da nova cafeicultura ${ }^{3}$ de São Paulo via trabalho assalariado;

- A criação de um mercado de trabalho rural e urbano, e ampliação do mercado de bens de consumo;

- A criação de um implante industrial ${ }^{4}$ subordinado à economia cafeeira, e;

- A consolidação do mercado de trabalho rural e urbano por meio da migração em massa de homens livres, que assegurou o baixo custo médio da força de trabalho.

Assim, São Paulo iniciava sua caminhada modernizadora em favor da primazia industrial brasileira, enquanto o Rio de Janeiro, então sede do governo, permanecia como principal articulador comercial e financeiro do país, participando ativamente das relações

\footnotetext{
O café apresentou-se como alternativa econômica para Minas Gerais, que, no entanto, não foi capaz de competir com a produção paulista, dada as melhores condições topográficas e de fertilidade da terra, além de uma mão-de-obra mais barata e abundante que também constituía mercado de consumo, que garantiram à segunda produtividade sem precedentes (DINIZ, 1981). Cano (2002) adiciona que a inclusão de técnicas avançadas na cafeicultura paulista no início do século XX proporcionou seu crescimento a custos decrescentes, ao passo que em Minas Gerais a cafeicultura se expandia sem inovações significativas, e no Rio de Janeiro (Vale do Paraíba) a cultura do café se expandia a preços crescentes. De fato, em 1919 a agricultura paulista era a mais tecnificada do país.

4 A esse respeito, Negri (1996) pondera que: "A indústria brasileira, em particular aquela que vai indicar mais tarde a liderança paulista, nasce atrelada à dinâmica da acumulação da economia cafeeira. Não há ainda industrialização, entendida stricto sensu como uma dinâmica assentada no capital industrial. Mas o nascimento industrial já indica a natureza contraditória de uma dinâmica que tende a negar-se pelo próprio crescimento da atividade fabril” (NEGRI, 1996, p. 6).
} 
comerciais atacadistas nas mais diversas regiões brasileiras e intermediando os fluxos da crescente região cafeeira que já avançavam sobre parte dos estados do Rio de Janeiro, Minas Gerais e São Paulo (CANO, 2002). Segundo Tavares (2000), o Rio de Janeiro vai permanecer como principal centro manufatureiro do país até 1920, quando começa a perder sua posição para São Paulo. A década de 1920 marca o início do declínio industrial da metrópole carioca, mas é apenas a partir de 1940que São Paulo passa a ocupar a posição de principal metrópole brasileira (CANO, 1997).

Minas Gerais se inseria perifericamente no processo de industrialização e desenvolvimento econômico brasileiro entre o final do século XIX até a metade do século XX, pois se manteve como base para investimentos voltados à produção de matérias-primas para abastecimento dos dois centros principais, Rio de Janeiro e São Paulo (QUEIROZ, 2013), apesar das diversas tentativas mineiras de industrialização já no início do século XIX, com experiências siderúrgicas, têxteis e alimentares ${ }^{5}$ (DINIZ, 1981). Isso não significa, contudo, que Minas Gerais se eximiu de esforços em prol da industrialização. Diniz (1981) e Cano (2002) observam que a partir da segunda década do século XX o Estado inicia a expansão de sua base siderúrgica, na expectativa de se reinserir no cenário econômico nacional.Contando com forte apoio estatal, setores institucionais modernos foram implantados $^{6}$, tais como a CEMIG, o DER,o BDMG e o INDI(no contexto do binômio Energia e Transporte), ao lado da crescente presença do capital estrangeiro. A consolidação desta iniciativa, segundo estes autores, só se dará na década de 50 com o crescimento da economia nacional e implementação do Plano de Metas, que expandiu a siderurgia, a metalurgia e a indústria de cimento em Minas Gerais ${ }^{7}$, além da sua inserção em posição privilegiada nos sistema de transporte nacional com a construção de Brasília ${ }^{8}$ (DINIZ, 1981; DULCI, 1999), que passa a criar uma nova força de polarização no país. Os efeitos multiplicadoresmais amplos de todas essas iniciativas foram, contudo, insuficientes para superar a estagnação econômica pela qual passava o Estado?

\footnotetext{
Para Diniz (1981), a experiência industrial mineira apresenta características próprias, e não pode ser reduzida ao "caso geral" do Brasil, pois tem estrutura produtiva singulares, assim como seu tempo econômico, o que a defasou em relação a evolução econômica nacional e a retardou industrialmente. É apenas na segunda metade do século XX que o Estado passa por um processo de acelerada recuperação do tempo perdido.

6 O fortalecimento do setor público também induz a constituição e concentração de uma poderosa tecnocracia, que vai desenvolver no estado uma ideologia industrializante (DINIZ, 1981; DULCI, 1999).

São desta época, por exemplo, a estatização da Acesita, a inauguração da Mannesmman e a construção da Usiminas.

8 A respeito da construção de Brasília, são interessantes as observações de Tavares (2000): No final dos anos 60, assiste-se à mudança da capital federal para Brasília, no Planalto Central. Para compensar as perdas que adviriam da mudança da capital, a União manteve no Rio de Janeiro as sedes das grandes empresas estatais, universidades e instituições de pesquisa, assim como órgãos como o Banco Nacional de Desenvolvimento Econômico. A prática de sustentação da economia fluminense, diga-se de passagem, não era nova. Desde a década de 1940, o Governo procurou localizar ali empreendimentos de grande porte, com o intuito de equilibrar a distribuição de recursos no espaço econômico mais desenvolvido do país, isto é, o triângulo São Paulo-Rio de Janeiro-Belo Horizonte (TAVARES, 2000, p. 94).

9 Cano (2002) destaca que a indústria mineira se estruturou de forma dispersa no início do século XX, em conformação com seu perfil demográfico, e se caracterizou pela pequena e média empresa. Próximo à metade do século XX, o autor relata que
} 
Diniz (1981) relaciona as razões para a incapacidade de superar o atraso industrial mineiro relativo até $1950^{10}$ :falta de um centro comercial exportador ${ }^{11}$, baixa velocidade de transição para o mercado assalariado e consequente atraso na formação de um mercado de trabalho e consumo, dispersão espacial da população e da produção dentro do Estado, sistema de comunicação precário, e a incapacidade de compensar a queda da produção cafeeira em 1930 com outros produtos. Soma-se a isso a concentração industrial em São Paulo e Rio de Janeiro, onde se fixou o capital estrangeiro, além da vocação mineira para a mineração e metalurgia, que trazia à tona uma gama de dificuldades técnicas de processamento e transporte, afora os grandes requisitos de capital. Para este autor, também pesaram as falsas teses sobre o atraso de Minas, associadas à incapacidade industrial e a vocação financista dos mineiros ${ }^{12}$.

Entre 1920 e 1970, São Paulo foi o local privilegiado da localização da indústria do país, e nesse período a concentração industrial cresceu continuamente (CANO, 1997; TAVARES, 2000). Cano (1997) observa que neste período o país apresentou uma das maiores taxas de crescimento econômico do mundo capitalista e não causou atraso ou estagnação à periferia nacional.Becker \&Egler (1993) e Becker (1997) adicionam que a onda de crescimento observado pelo Brasil a partir de 1967 foi capaz de alterar sua posição na estrutura da economia-mundo, deixando a posição de semiperiferia para tornar-se potência regional ${ }^{13}$.

É importante ressaltar, contudo, o contexto em que se inseria o parque industrial brasileiro, onde haviaindústrias pesadas modernas, instaladas a partir de 1930 e compatíveis com a então fase capitalista mundial, e indústrias metal-mecânicas, em sua maioria filiais de empresas internacionais. Já as indústrias de bens não duráveis de consumo, cuja origem remontava ao século XIX, encontravam-se atrasadas e obsoletas, muitas vezes com administração familiar decadente (DINIZ, 1981). Estecenário teve efeitos diferenciais na indústria mineira, pois incentivou o crescimento da produção de bens intermediários, a expansão do

\footnotetext{
"a despeito da subordinação da cafeicultura de Minas Gerais, que não proporcionou a criação de um complexo cafeeiro, e da débil recuperação de sua agricultura, sua expansão industrial e bancária foi notável. Isso, contudo, (e por isso mesmo) não foi capaz de evitar um elevado êxodo rural mineiro que, segundo o censo de 1939, fazia com que Minas Gerais perdesse 8,6\% de sua população para o resto do país, batendo precocemente um recorde nacional de expulsão humana" (CANO, 2002, p. 59).

10 Apesar de tais razões históricas, relata Diniz (1981) que em 1950 Minas Gerais estava preparada para experimentar uma forte expansão industrial, pois já possuía infraestrutura básica, um parque industrial relativamente desenvolvido, com viés produtivo metalúrgico e de cimento. Entretanto, mesmo com a economia preparada, a economia brasileira entrou em recessão, o que acabou frustrando a economia mineira.

${ }_{11}$ A necessidade de centralização da economia mineira foi um requisito para se alcançar o progresso econômico, já esgotado por obstáculos econômicos tais como falta de acesso ao mar, estrutura comercial e financeira localizada fora do estado, a topografia, a deficiência dos transportes e a diminuição da fertilidade da terra. Desdobramentos do processo de centralização focado na industrialização são verificados a partir de 1950 (DINIZ, 1981).

12 Este último com forte relação com os resultados divulgados no "Diagnóstico da Economia Mineira", produzido pelo BDMG em 1968, que, entre outros, serviu ao fortalecimento do poder da tecnocracia mineira em detrimento de parte das elites políticas tradicionais (DINIZ, 1981; DULCI, 1999; GODOY et al., 2010).

${ }^{13}$ Becker \&Egler (1993) e Becker (1997) se referem ao crescimento econômico observado no país entre 1967 e 1982.
} 
capital e a especialização produtiva, além de iniciar um processo de centralização que facilitou a expansão industrial. Para Diniz (1981), o "processo agiu no sentido de preparar ou fortalecer as bases para que o parque industrial já existente experimentasse altas taxas de crescimento, quando as condições gerais da economia assim o permitissem (DINIZ, 1981, p. 147)”.

Toda maneira, o impressionante crescimento nacional impulsionado por São Paulo, associado ao contexto econômico internacional, revelou vantagens e desvantagens aglomerativas, que por sua vez acabaram levando o país a um processo de reestruturação produtiva e territorial, pautado na desconcentração da indústria paulista ${ }^{14}$ a partir dos anos de 1970.

O termo "reestruturação" é largamente utilizado em diversas áreas do conhecimento ${ }^{15}$, e em termos gerais diz respeito ao momento em que há a ruptura de uma estrutura estável e fixa e sobreposição dessa por outra, que a substitui (LENCIONI, 1998). No contexto capitalista, a reestruturação é um fenômeno socioespacial em resposta à busca de soluções para as crises intrínsecas ao seu próprio funcionamento (ALONSO, 2004), e pode assumir vários nomes, tais como reestruturação urbana, reestruturação social, reestruturação espacial, reestruturação organizacional, reestruturação econômica, reestruturação industrial e reestruturação produtiva (GOMES, 2011). Ainda a esse respeito, Soja (1993) esclarece que:

A reestruturação não é um processo mecânico ou automático, nem tampouco seus resultados e possibilidades potenciais são predeterminados. Em sua hierarquia de manifestações, a reestruturação deve ser considerada originária de e reativa a graves choques nas situações e práticas sociais preexistentes, desencadeadora de uma intensificação de lutas competitivas pelo controle de forças que configuram a vida material. Assim, ela implica fluxo e transição, posturas ofensivas e defensivas, e uma mescla complexa e irresoluta de continuidade e mudança. Como tal, a reestruturação se enquadra entre a reforma parcial e a transformação revolucionária, entre a situação de perfeita normalidade e algo completamente diferente. (SOJA, 1993, p.194)

ParaBaeninger (2014), os processos de reestruturação produtiva assistidos no mundo capitalista desde o final do século XX introduziram transformações econômicas, políticas e sociais, em boa medida à procura de novos meios de inserção na dinâmica global ${ }^{16}$. Como consequência, verificaram-se alterações dos processos urbanos, o incremento da velocidade das transformações tecnológicas, a inserção das cidades pequenas e médias no dinamismo regional, e o processo de inversão dos fluxos migratórios.

${ }^{14}$ O processo de desconcentração da indústria paulista já foi exaustivamente discutido por autores como Diniz \&Crocco (1996), Pacheco (1996), Negri (1996), Cano (1997), Azzoni (2002), Oliveira (2007), Andrade \& Serra (2013), Queiroz (2013), Saboia (2013) e Matos (2014), entre outros, de modo que aqui não será realizada uma recuperação retrospectiva dos processos concernentes a este momento da economia brasileira, mas sim, uma exposição geral com objetivo de fundamentar teoricamente os resultados a que se pretende atingir neste artigo.

15 Apenas sobre o termo "reestruturação", Gomes (2011) relaciona as contribuições de mais de cinquenta autores para os diferentes enfoques da temática da reestruturação, no bojo da sociologia, engenharia da produção, economia, história econômica, geografia e educação.

16 No caso brasileiro, Azzoni (2002) ressalta que a abertura tardia e acelerada do mercado implicou em um ajustamento produtivo em ritmo acentuado, que evidenciou diversos setores ineficientes até então protegidos, e implicou na liquidação de alguns setores produtivos espacialmente concentrados. 
No Brasil, o processo de reestruturação produtiva inicia-se, segundo Gomes (2011), com a crise do modelo de desenvolvimento fundamentado na política de "substituição das importações" e se potencializa nos anos 1990, com a política neoliberal e a abertura econômica. Para Diniz \&Crocco (1996), essa reestruturação produtiva associada à desconcentração da indústria paulista acarretou em relativa dispersão geográfica da indústria para a maioria das Regiões e Estados brasileiros. Entretanto, essa dispersão orientou-se no sentido de uma reconcentração geográfica -uma desconcentração concentrada - que vai do Centro de Minas Gerais ao Nordeste do Rio Grande do Sul, onde emergiram novas áreas industriais, predominantemente em cidades de porte médio com forte integração regional produtiva e comercial.

No plano nacional, a bibliografia pesquisada aponta para uma série de fenômenos que se associam ao processo de desconcentração industrial nacional, a saber:

- O processo de reversão da polarização da Área Metropolitana de São Paulo (DINIZ \& CROCCO, 1996; NEGRI, 1996; ANDRADE\& SERRA, 2013; SABOIA, 2013; QUEIROZ, 2013; MATOS, 2014);

- O surgimento de deseconomias de aglomeração $0^{17}$ e pressões ambientais nas áreas intensamente industrializadas (NEGRI, 1996; PACHECO, 1996; MATOS, 2014);

- O desenvolvimento da infraestrutura, conjugado com o crescimento urbano e de serviços modernos em várias cidades brasileiras e integração do mercado nacional(DINIZ \& CROCCO, 1996; PACHECO, 1996; NEGRI, 1996; CANO, 1997; OLIVEIRA, 2007; ANDRADE\& SERRA, 2013; MATOS, 2014);

- A forte intencionalidade da política econômica em promover o processo de desconcentração industrial (DINIZ, 1981; DINIZ \& CROCCO, 1996; PACHECO, 1996, NEGRI, 1996; MATOS, 2014);

- A distribuição dos recursos naturais e o crescimento da produção agrícola e mineral, com grande expansão de suas fronteiras territoriais (DINIZ, 1981; DINIZ \& CROCCO, 1996; PACHECO, 1996; NEGRI, 1996; CANO 1997; AZZONI, 2002);

- O perfil relativamente desconcentrado do sistema urbano brasileiro, a intensificação da urbanização nas regiões norte, nordeste e centro-oeste do país, e sua incorporação na dinâmica da geração de riqueza (PACHECO, 1996; CANO, 1997; FERREIRA \& MATOS, 2004);

\footnotetext{
${ }_{17}$ Segundo Negri (1996), "por "deseconomias de aglomeração" entendia-se um conjunto de variáveis, entre as quais se destacam os maiores custos de transportes, de terrenos, de serviços e de infraestrutura urbana, incluindo-se outras que provocavam alteração na organização da produção e na sua produtividade, como maiores dispêndios de tempo com transporte, ampliação do poder sindical da classe trabalhadora, questões ambientais, com deterioração das condições de vida nos grandes centros urbanos, queda na produtividade do trabalho, etc." (NEGRI, 1996, p. 15).
} 
- Os impactos da crise econômica, das áreas industrializadas, e da orientação exportadora nacional (DINIZ, 1981; PACHECO, 1996;CANO, 1997; AZZONI, 2002);

- Os ajustes microeconômicos internos às empresas com focalização na produção(PACHECO, 1996; ANDRADE\& SERRA, 2013);

- As vantagens fiscais, creditícias, logísticas e de infraestrutura oferecida pelos governos municipais (DINIZ, 1981; SABOIA, 2013);

- A disponibilidade de mão de obra, menores níveis salariais e menores níveis de articulações trabalhistas existentes fora dos grandes centros (DINIZ, 1981; SABOIA, 2013).

Os processos econômicos e territoriais iniciados em 1970 tiveram fortes efeitos sobre a reconfiguração da rede urbana brasileira ${ }^{18}$, e a partir de 1990, outros fatores passam a compor o leque de fenômenos associados à reestruturação nacional e reconcentração das atividades produtivas, conforme relacionam Andrade\& Serra (2013): mudanças tecnológicas, maior abertura comercial, criação do MERCOSUL, mudança no papel do Estado e a diminuição da importância dos recursos naturais.

Neste ínterim, Minas Gerais se beneficiou tanto com a atuação do Governo Federal na ampliação da infraestrutura viária que articulou os principais centros produtores do sudeste com a nova capital nacional, quanto incorporou os incrementos verificados na agropecuária e na mineração, que tiveram importantes desdobramentos em termos de fomento à estruturação urbana e do setor de serviços.Além disso, desenvolveu-se um aparato logístico para a fluidez dessas atividades (DINIZ \& CROCCO, 1996; AZZONI, 2002), que difundiu efeitos multiplicadores sobre toda a economia (QUEIROZ, 2013), e vieram sedimentar a infraestrutura urbano-industrial do estado (VALLE et al., 2014). Ganha maior dimensão o processo de implantação de complexos industriais e especialização na produção metal-mecânica com a instalação da Usiminas (Ipatinga), FIAT (Betim), Mercedes (Juiz de Fora) e o polo Tecnológico Sul (Santa Rita do Sapucaí). Ademais, a base econômica da extração mineral mantinha-se firme e em expansão no período. Toda forma, ressalta-se que o desenvolvimento daí decorrente não beneficiou todo estado de forma homogênea ${ }^{19}$, já que se deu com maior vigor nas regiões centro-sul e triângulo mineiro (em razão de melhores vantagens locacionais), e em menor grau nas regiões norte e nordeste de Minas.

\footnotetext{
18 Segundo Valle et al.(2014), entre 1960/70, "a população brasileira experimentou os efeitos da transição demográfica, derivados das quedas da mortalidade e da fecundidade, e a criação de novas aglomerações urbanas, que acabaram por delinear um processo firme de interiorização da rede urbana” (VALLE et al., 2014, p. 01) .

19 Como bem pontua Perroux (1955), “O fato, rude mas verdadeiro, é o seguinte: o crescimento não aparece simultaneamente em toda parte. Ao contrário, manifesta-se em pontos ou polos de crescimento, com intensidades variáveis, expande-se por diversos canais e com efeitos finais variáveis sobre toda a economia” (PERROUX, 1955, p. 146).
} 
Para Diniz (1981), um conjunto de fatores indicavam Minas Gerias como localização privilegiada para a etapa expansiva da indústria nacional, tais como a existência de recursos naturais, a disponibilidade de infraestrutura econômica (energia transportes e comunicações), a existência da indústria básica (metalurgia e cimento).Novasindústrias básicas eram atraídas e a mineração contribuía para a afirmação da indústria de bens de capital.A posição geográfica do Estado, o aparato institucional de apoio à industrialização, os incentivos fiscais como mecanismos de retorno dos investimentos e de aumento da taxa de lucros, colaboraram com reconfiguração de novas alternativas regionais para a localização industrial(o norte de Minas com os incentivos da SUDENE e a região sul de Minas como área para a desconcentração de São Paulo).No período do "milagre econômico"de fins da década de 1960, Minas apresentou vantagens comparativas para atração do capital estrangeiro, - que passava por uma fase de excesso de liquidez internacional propiciadas pelo auge do capitalismo. Nesse momento detinha um significativo mercado consumidor, tranquilidade política para as empresas, baixo nível salarial, apoio efacilidades governamentais.

No esteio das mudanças tecnológicas vinculadas à chamada reestruturação produtiva, é estabelecido um novo padrão tecnológico centrados nas indústrias da eletrônica, informática, de biotecnologia e de novos materiais, atuantes em sistemas flexíveis de produção, cuja principal característica é sua capacidade de ajuste de quantidades de produção e de processos, sem efeitos negativos em seus níveis de eficiência (PIQUET, 2007), além de sua capacidade de retornos favoráveis em grande escala a curto e médio prazo (BERTELLI, 2014). Este novo paradigma produtivo acaba por influenciar os modelos locacionais no sentido da desconcentração industrial e na concentração do capital ${ }^{20}$, na medida em que acarretam em barateamento nos custos de transferências (ANDRADE E SERRA, 2013, FERREIRA, 2013).

Um efeito interessante dos sistemas de produção flexíveis que passa a marcar a atualidade é relatado por Bertelli (2014). Segundo este autor, os rearranjos locacionais levam a formação de pequenas e médias empresas que propulsionam o crescimento e desenvolvimento econômico, dividem a força motriz da economia, deixando de estar alocados exclusivamente em grandes empresas e se consolida em um setor que, embora se mostre pulveriza-

\footnotetext{
20 Salienta Ferreira (2013) que "a desconcentração das plantas industriais não significa, necessariamente, descentralização do capital. As sedes das empresas continuam localizando-se nas grandes metrópoles, assim há simultaneamente desconcentração industrial e centralização do capital; há despolarização e polarização" (FERREIRA, 2013, p. 45). Nesse debate, Azzoni (2002) observa que na segunda metade dos anos 80 e nos anos 90 houve um arrefecimento no processo de desconcentração, e Saboia (2013) indica que na década de 2000 o processo de desconcentração foi intenso, beneficiando a região sul do Brasil e induzindo certo esvaziamento industrial das metrópoles do sudeste brasileiro. Sob o ponto de vista das vantagens aglomerativas, Matos (2014) indica que o processo de desconcentração sintetiza os custos crescentes das deseconomias de escala e vem beneficiar as cidades secundárias (geralmente de médio porte). Estes centros intermediários passam a serem locais alternativos de geração de renda e emprego ao mesmo tempo em que modernizam sua infraestrutura e serviços, aumentam sua produção, diversificam suas atividades econômicas e participam ativamente do desenvolvimento do sistema urbano brasileiro (MATOS, 2000). O desenvolvimento econômico destas aglomerações urbanas não metropolitanas são talvez um evidência relevante do processo de desconcentração industrial nos dias de hoje.
} 
do (dados os crescentes níveis de especialização), são capazes de trabalhar de forma articulada. Todavia, este novo arranjo não exclui a validade do anterior: a construção de zonas industriais continua sendo uma estratégia viável para a formação de arranjos produtivos. A diferença é que, ao invés do predomínio de grandes indústrias de lógica fordista, subespaços industriais passam a ser um instrumento de reorganização de estruturas internas, onde pequenos e médios produtores trabalham mutuamente em prol do desenvolvimento do setor.

Consequências do processo de desconcentração industrial e reestruturação produtiva do país são vistas até hoje, com a ampliação econômica e demográfica das cidades médias, os constantes investimentos em infraestrutura viária e de telecomunicações, além do fortalecimento da agroindústria. Minas Gerais se beneficiou desse processo a ponto de ultrapassar o Rio de Janeiro e tornar-se a segunda mais importante economia do país (AZZONI, 2002; VALLE et al., 2014), fruto de ações do Estado e esforços que se iniciaram no início do século XX.

É evidente que a urbanização no Brasil, em pouco mais de três décadas, veio acompanhada
de mudanças nas atividades ocupacionais com a industrialização e o avanço do terciário, al-
terações no padrão de consumo e nos estilos de vida, reorientação política resultante do de-
clínio das velhas oligarquias rurais. Nesse processo, o país assistiu a consolidação de paisa-
gens artificiais resultantes da construção de grandes infraestruturas e edificaçóes que exigi-
ram muito cimento, aço, petróleo e outros minerais, além de um alto consumo energético.
Paralelamente, o tamanho do Estado aumentou como nunca se cogitara antes, e hoje, mes-
mo após a forte privatização do período 1994-2002, a administração e a máquina pública
permanecem fortes e atuantes, e, não obstante as diferentes posiçães teóricas sobre o tema,
o Estado é um fator ainda determinante capaz de gerar variados incentivos econômicos, sem
os quais a interiorização da urbanização se inviabiliza. (MATOS, 2012, p. 90).

1. Em síntese, com base no exposto, é possível visualizar as reestruturações territoriais mineiras a partir do processo de urbanização e industrialização do Brasil, delineadas em cinco fases:

2. Meridionalização sudeste de Minas Gerias pela polarização do Rio de Janeiro, herdeira do longo tempo em que o Rio de Janeiro não só foi a capital do Império, como a capital da República.

3. Meridionalização sudoesteem razão da marcha do café para o oeste e pela influência de São Paulo, ainda que em 1940 ela não seja tão contundente como será mais tarde.

4. A força centrípeta da polarização de Belo Horizonte rumo à metropolização. A capital mineira entre 1950 e 60 cresce muito e em 1973 centraliza uma região metropolitana, junto a outras oito capitais brasileiras. SeMinas perdia centralidade, Belo Horizonterefaz essa centralidade. 
5. Setentrionalização noroeste dada pela força de atração de Brasília e a desconcentração metropolitana. Em 1970 Brasília ainda está dando seus primeiros passos, mas em 1980 já tem um poder de influência que pode ser lido espacialmente. Este poder está na interiorização da rede urbana brasileira, que coincide com o processo de desconcentração ${ }^{21} \mathrm{e}-$ conômico-demográfico,quando metrópoles perdempopulação nas trocas populacionais.

$\mathrm{Na}$ atualidade uma espécie de tripé de articulação territorial estaria em marcha: a) na expansão integradora dos meios de transporte e circulação de todo tipo no território nacional, ou seja, um momento de integração territorial promovido pelos meios de circulação e transporte (incluindo as redes de comunicação e energia elétrica); b) proliferação de cidades de porte médio que passaram a ter um crescimento demográfico mais expressivo do que das antigas metrópoles; c) extensão territorial do agronegócio, o que fez surgiras cidades do agronegócio, especialmente nos grandes espaços da agroindústria do Brasil central,o que inclui partes de Minas Gerais.

Por fim,Vainer (2011) chama a atenção para a questão da paulatina fragmentação territorial verificada no Brasil, intensificada pelos processos de reestruturação, decorrente principalmente de grandes projetos, do neo-localismo competitivo e empreendedorista, e de velhos regionalismos e localismos, que acarretam o que o autor chama de "acomodação subordinada às formas contemporâneas da globalização" (VAINER, 2011, p. 10), cuja contrapartida dá-se em uma integração continental submetida às novas escalas e dinâmicas espaciais do capital. Isso significa que, na ânsia de se posicionar diante de interesses globais, os territórios brasileiros deixam para trás formas solidárias de reprodução (PEREIRA, 2013) em favor de outras, mais fascinantes e convidativas à primeira vista, mas que trazem consigo um viés perverso alimentado pelo primado da competição excludente.

\section{Evidências do processo de modernização e reestruturação dos municípios mineiros}

Matos (2012) postula que o processo de desconcentração espacial econômico-demográfico ganha consistência se apoiado em uma rede de localidades centrais relativamente densas e em expansão. Para ele, os impulsos de descentralização redinamizam a própria rede urbana, difundem inovações originárias das grandes metrópoles, viabilizam a ocupação de vazios demográficos e revitalizam regiões semi-estagnadas(MATOS, 2012, p. 88). Além disso, o processo de interiorização da urbanização pode significar melhoria das condições de vida, do emprego e da renda da população.

\footnotetext{
${ }^{21}$ Aqui, a desconcentração deve ser lida sob a lógica centro-periferia. Ou seja, em primeira instância a desconcentração se dá em favor da sua periferia imediata. Já em um segundo momento, tem-se uma espécie de continuidade do processo de desconcentração, mas os protagonistas não serão estritamente os municípios periféricos das regiões metropolitanas, mas as cidades médias.
} 
No bojo do processo de modernização industrial e reestruturação territorial até aqui exposto, buscar-se-á responder, através de mapas e dados, à seguinte pergunta: da configuração territorial e produtiva na Minas Gerais de 1940, o que permaneceu até 2010? Em primeiro lugar, expõe-se a grande fragmentação territorial que se verificou neste período, quando o número de municípios passou de 288 para $853^{22}$ (IBGE, 2011). Além disso, dos 288 municípios em 1940, apenas 77 (26,7\%) não tiveram qualquer perda territorial por emancipações até 2010.

Em segundo lugar, cabe discutir como se configuravam as principais centralidades nos dois anos selecionados. Para isso, estabeleceram-se dois recortes espaciais para fins analíticos:

Para o primeiro recorte -em que se adotou como critério a população urbana de 10 mil habitantes urbanos em 1940 (38 municípios) e 50 mil habitantes urbanos em 2010 (57 municípios) - foram selecionados os municípios de maior relevância urbana nos seus respectivos anos de referência (doravante chamados de "municípios-destaque"). O pressuposto fundamental é de que estes municípios representam centralidades dinâmicas e altamente produtivas na configuração da rede urbana mineira em suas respectivas épocas.

O segundo recorte refere-se à definição dos macro espaços de análise em que se inserem os municípios-destaque. Para tanto, fez-se o agrupamento das mesorregiões do IBGE (IBGE, 2010) em cinco, a saber: Norte (Norte de Minas, Jequitinhonha e Mucuri), Leste (Vale do Rio Doce e Zona da Mata), Sul (Sul e Sudoeste de Minas), Oeste (Noroeste de Minas e Triângulo Mineiro/ Alto Paranaíba), Centro (Central Mineira, Metropolitana de Belo Horizonte, Oeste de Minas e Campo das Vertentes).

A Figura $1^{23}$ traz a configuração geográfica dos municípios destaque em 1940 e 2010. Note-se que a maior parte dos municípios que se destacam em 2010 já se destacava em 1940 ou já existiam. Além disso, a maioria delestiveram perdas territoriais.Contudo, nenhum dos municípios que se emanciparam dos originais de 1940 figuram entre os mais relevantes em 2010. Dos 57 municípios-destaque em 2010, apenas 11 (19,3\%) se emanciparam após 1940.

\footnotetext{
${ }^{22}$ Entre 1940-50 foram registrados 99 novos municípios; entre 1950-60, 69; entre 1960-70, 239; entre 1970-80, 0; entre 1980-91, 1; entre 1991 e 2000, 130; e entre 2000 e 2010, 0 (IBGE, 2011).

23 Todos os mapas apresentados aqui foram produzidos em ambiente ArcGIS 10.1.
} 
Figura 1: Síntese dos municípios-destaque em 1940 e 2010.

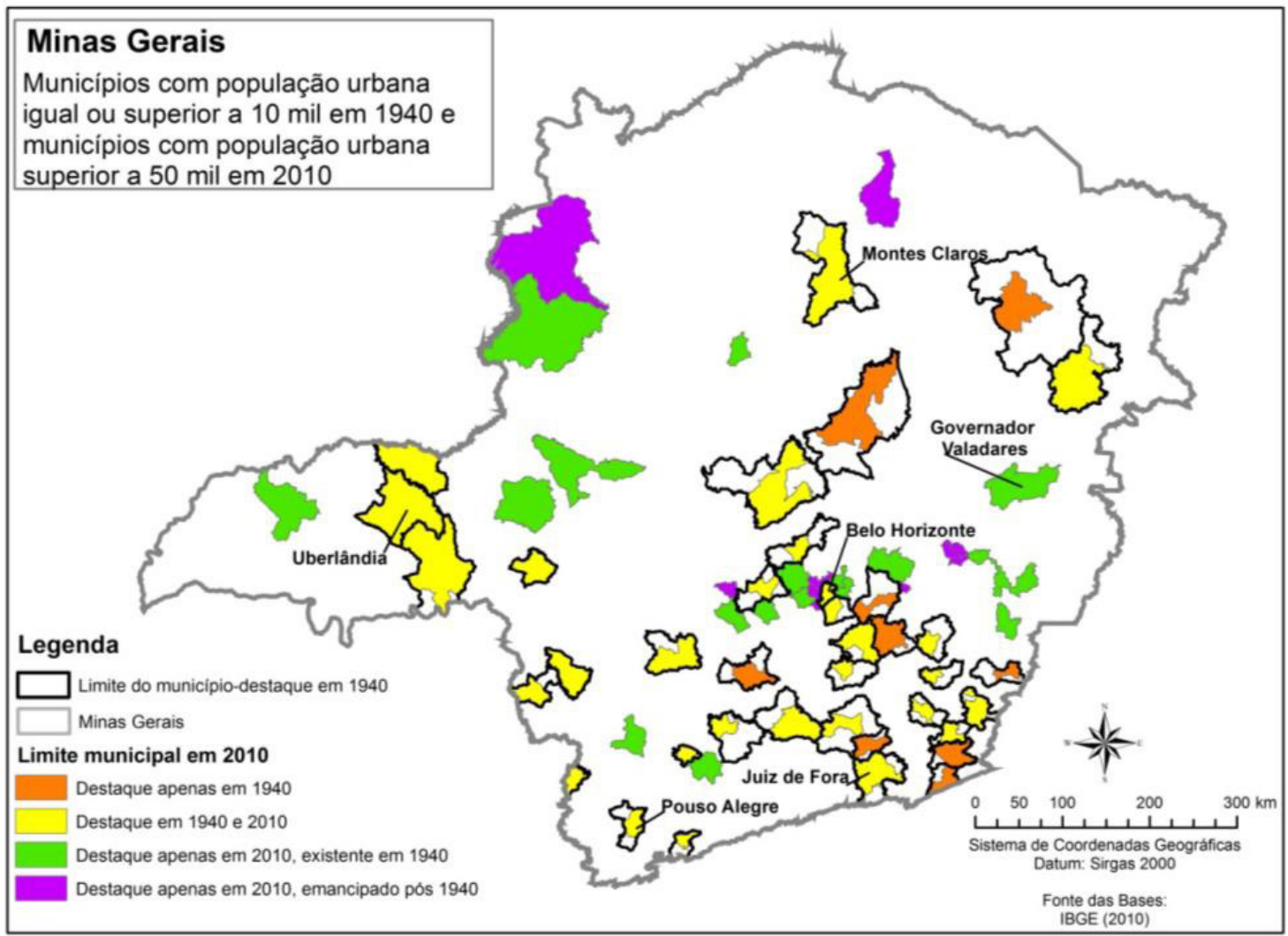

OQuadro 1 traz dados sobre a população e a produção dos municípios-destaque em relação aos demais municípios mineiros nos dois anos analisados. ${ }^{24}$ Dele decorrem as seguintes constatações:

- Em 1940, os municípios-destaque concentravam apenas $26,4 \%$ da população total de Minas Gerais, e sua população média era apenas 2,35 vezes maior que a população média dos demais municípios mineiros, em grande contraste com o cenário observado em 2010 , em que $54,4 \%$ da população se concentrava nos municípios-destaque, cuja população média era 16,6 vezes superior à dos demais municípios;

- Entre 1940 e 2010, verificou-se um crescimento de $299,7 \%$ da população média dos municípios-destaque, e queda de $-43,4 \%$ na população média dos demais municípios;

- No caso da população urbana, em 1940 verifica-se que $46,4 \%$ se concentrava nos municípios-destaque, proporção que passou para $61,6 \%$ em 2010 . A população urbana média nos municípios destaque era 5,7 vezes maior que nos demais municípios no primeiro ano, e no segundo ano passoua ser 22,5 vezes superior;

${ }^{24}$ Os dados referem-se ao Produto Interno Bruto Municipal (PIB) referentes a 1939 e 2010 , apresentados a preços constantes (R\$, a preços do ano 2000 (mil)) (IPEADATA, 2015). 
- A população urbana média dos municípios-destaque cresceu em 775,2\% entre 1940 e 2010, tendência que se observou nos demais municípios mineiros com menor intensidade $(121,7 \%)$;

- Em relação à produção, verifica-se que $42,8 \%$ dela se concentrava nos municípios-destaque em 1940, já em 2010 esta proporção cresce para 66,1\%. No primeiro ano, o PIB médio dos municípios-destaque era apenas 4,9 vezes superior ao dos demais municípios, proporção fortemente díspar da observada em 2010, de 27,2 vezes. Isso ocorreu porque, enquanto o PIB dos municípios-destaque cresceu mais de $3.000 \%$ entre 1940 e 2010 , o dos demais municípios apresentou crescimento de $465 \%$, ritmo 6,5 vezes inferior.

- Apesar disso, a relação entre o PIB per capita entre os municípios-destaque e os demais diminui entre 1940 e 2010: no primeiro ano, este valor nos municípios destaque era $108,8 \%$ superior ao dos demais, ao passo que em 2010 essa diferença caiu para $63,5 \%$.

- No caso do Valor do PIB adicionado na agropecuária, percebe-se forte domínio dos demais municípios em 1940, quando detinham $79 \%$ da produção, evoluindo para 80,9\% em 2010. Curiosamente, o valor adicionado médio na agricultura nos municípios-destaque é superior ao dos demais municípios em ambos os períodos, 1,74 vezes em 1940 e 3,3 vezes em 2010.

- Já em relação ao valor do PIB adicionado na indústria, verifica-se que em 1940 já havia predominância de sua geração nos municípios-destaque, com $60,6 \%$, proporção que sobe para 70,4\% em 2010. No período analisado, a diferença entre o valor adicionado médio da indústria entre os municípios-destaque e os demais municípios triplica, pois era 10,1 vezes superior em 1940 e passa a ser 33,2 vezes superior em 2010.

- $\mathrm{O}$ valor do $\mathrm{PIB}$ adicionado aos serviços segue tendência semelhante à indústria. Em 1940, 55,6\% do seu valor concentrava-se nos municípios-destaque, proporção que subiu para 70,4\% em 2010. A proporção do valor médio adicionado no setor de serviços em 1940 é 8,2 vezes maior que o dos demais municípios em 1940, diferença que quadriplica para 33,2 vezes em 2010 . Note-se que o valor adicionado no setor de serviços dos demais municípios em 2010 é bastante próximo ao observado nos municípios-destaque em 19400 que deve exprimir a generalização da urbanização na maior parte do território de Minas Gerais.

- De um modo geral, observa-se que a composição do PIB sofreu forte mudança de perfil tanto nos municípios-destaque quanto nos demais municípios ${ }^{25}$. No caso dos

${ }_{25}$ Para fins de comparação, o valor adicionado dos impostos não foi considerado na composição do PIB do ano de 2010. 
municípios-destaque, em 1940, o valor adicionado no setor primário era de 19,2\%, no secundário de $22,1 \%$ e no terciário de 58,8\%, proporção que se alterou em 2010 para 2,5\%, 35,8\% e 61,8\%, respectivamente. Nos demais municípios, observava-se em 1940 um valor adicionado no setor primário de 54,1\%, no secundário de 10,8\% e no terciário de 35,1\%, e em 2010 observou-se 20,2\%, 29,3\% e 50,5\% nos três setores. Fica clara a perda da importância relativa do setor primário e a força da industrialização em ambos os grupos, chegando a superar o setor primário no segundo grupo. Em 2010, o setor de serviços ratifica sua importância enquanto setor de apoio à indústria, e participa com mais da metade da composição da produção municipal média.

A Figura 2 traz a distribuição dos municípios-destaque em 1940 e 2010 por PIB, classificados através do método de partição em Quantis ${ }^{26}$. Verifica-se em 1940 a força do vetor econômico Sudeste do estado (Meridionalização Sudeste), ainda polarizado pela Capital Federal. Belo Horizonte,ainda em ascensão econômica, rivalizava com a importância industrial de Juiz de Fora beneficiada pela articulação ferroviária existente na Zona da Mata. O Triângulo Mineiro também se destaca, sobretudo pela sua produção agropecuária focada no mercado consumidor paulista. No vetor Centro-Norte, há um número significativamente menor de municípios-destaque, alguns deles vivendo os últimos suspiros de uma economia que fora pujante no século XIX, como Diamantina e Araçuaí. Já na porção Sudoeste do Estado, municípios de antiga tradição política e importância econômica se encontravam em relativa decadência nas primeiras décadas do século XX, mas começavam a ser beneficiados pela polarização de São Paulo. Em 1940, as porções Noroeste e Leste mineiras não possuem centralidades relevantes.

A observação das evidências cartográficas de 2010 apontam outros cenários, certamente associados aos efeitos da Meridionalização Sudoeste resultante da polarização de São Paulo, e da Setentrionalização Noroeste resultante da polarização de Brasília.Além disso, é notável acentralização capitaneada pela metropolização da capital mineira e a dinamização da porção leste do território provocada pelo avanço da siderurgia. Neste ano, há uma distribuição mais uniforme dos municípios-destaque pelo Estado. Além da evidenciação de municípios em áreas pouco dinamizadas em 1940, tais como as porções noroeste e leste, verifica-se o fortalecimento das regiões polarizadas por São Paulo (Sul e Triângulo), e a desaceleração daqueles polarizados pelo Rio de Janeiro ${ }^{27}$. Como já evidenciado na Figura 1, a maior parte dos municípios que deixou de fazer parte do grupo de destaque localizam-se no eixo centro-sudeste do estado.

${ }_{26}$ Trata-se de um método de classificação em que cada agrupamento contém um número igual de entidades, e é adequada para dados distribuídos linearmente. Aqui, optou-se pelo uso de quatro classes, ou quartis, para a classificação.

${ }^{27}$ Não significa necessariamente que estes municípios perderam força, mas sim que o ritmo de crescimento dos demais foi superior. 
Quadro 1: Municípios em 1940 e 2010 por porte populacional urbano e Produto Interno Bruto. Fonte dos dados: IBGE (2011) e IPEADATA (2015)

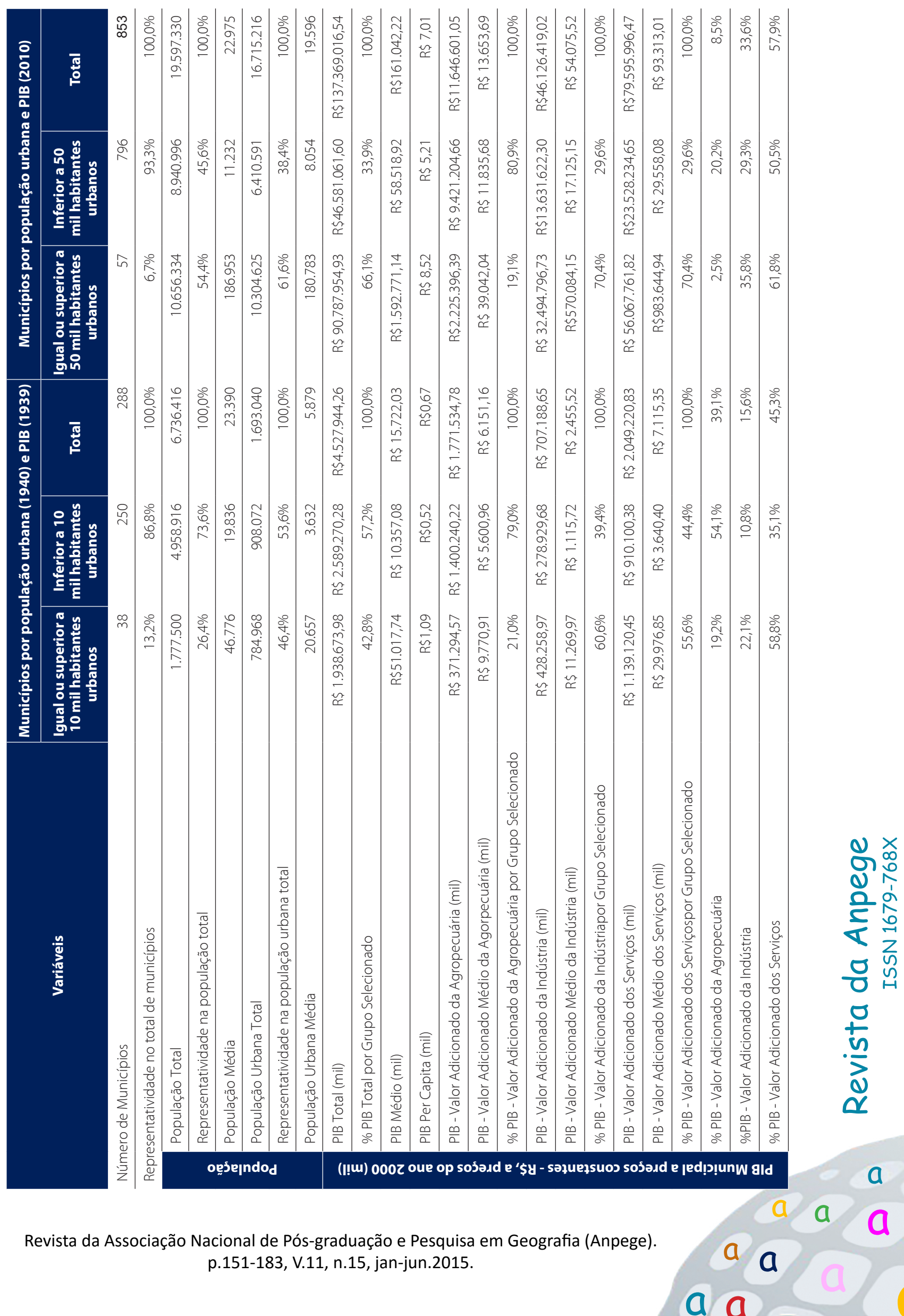


Figura 2: Municípios-destaque em Minas Gerais em 1940 e 2010 segundo seu Produto Interno Bruto (R\$ 1.000,00, a preços constantes corrigidos para 0 ano 2000).

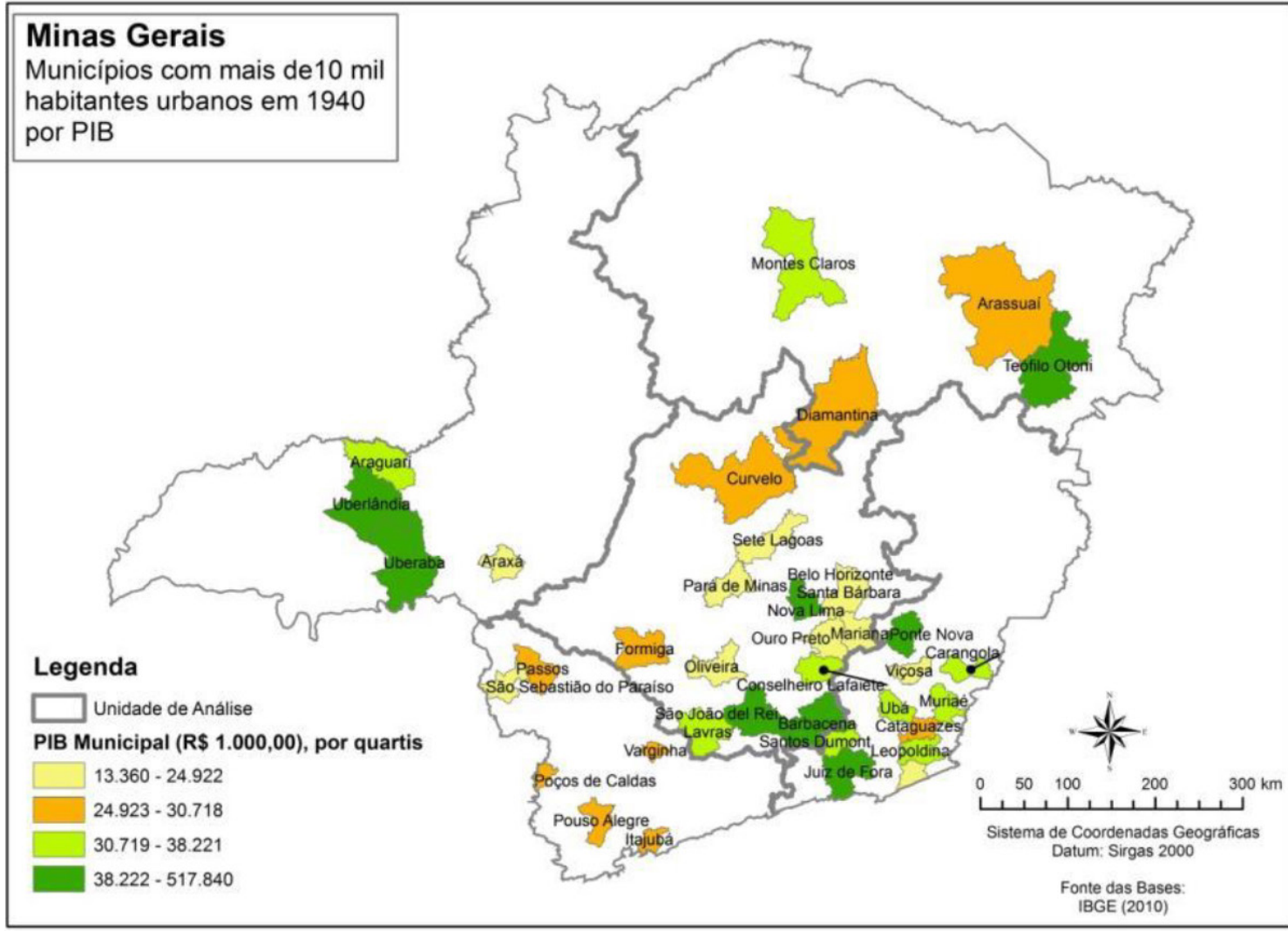

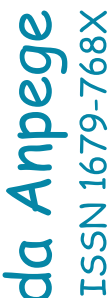

$\frac{0}{4}$

\section{Minas Gerais}

Municípios com mais de 50 mil habitantes urbanos em 2010 por PIB

\section{Legenda}

$\square$ Unidade de Análise

PIB Municipal (R\$ 1.000,00), por quartis

$152.945-494.193$

$494.194-672.085$

$672.086-1.505 .758$

$1.505 .759-23.051 .429$

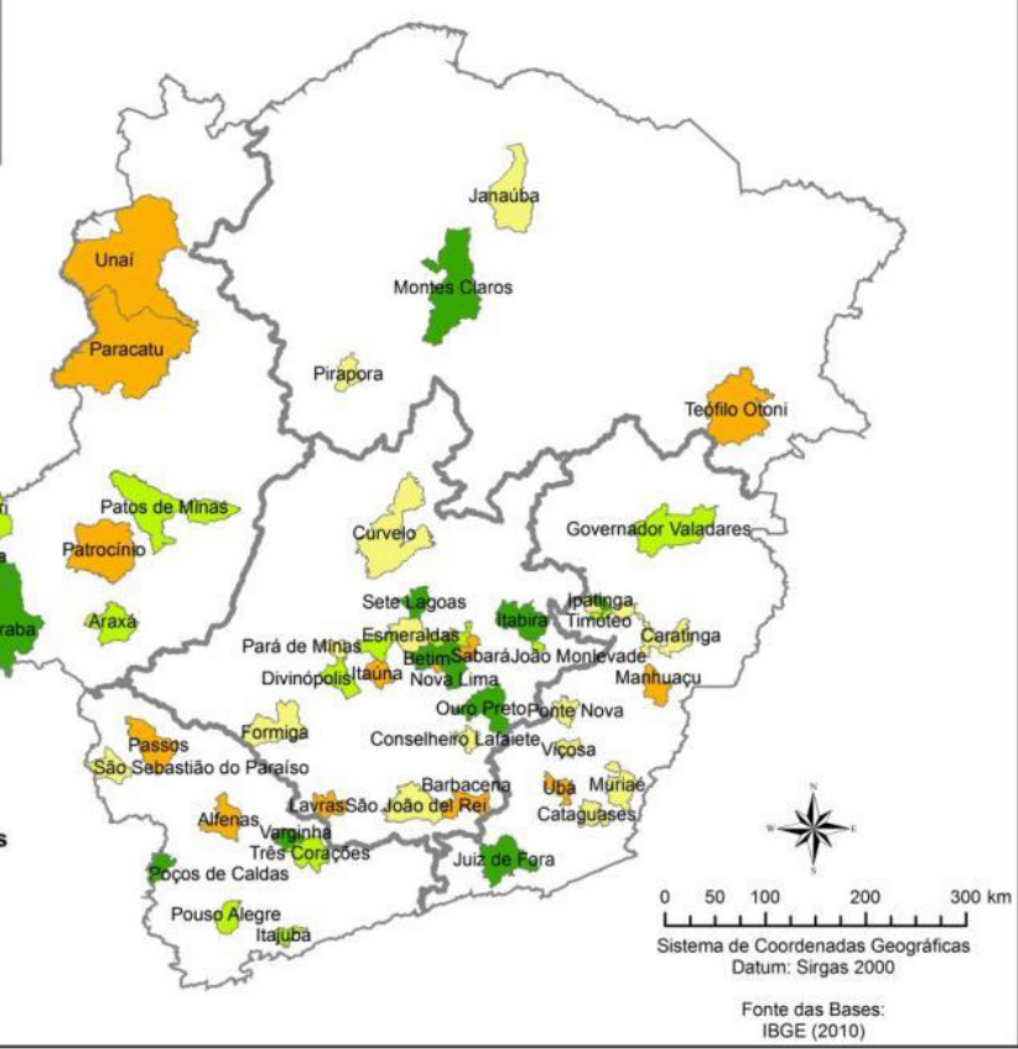

a

a 
Nas figuras a seguir são apresentadas, de forma detalhada, a disposição dos municípios-destaque por Subespaço de análise, articulação viária principal ${ }^{28}$ e rios mais importantes. Ressalte-se que em 1940 ainda predominava o transporte ferroviário de passageiros e bens, e que o único trecho rodoviário pavimentado era da rodovia União-Indústria, a ligar Juiz de Fora ao Rio de Janeiro.

Na Figura 3 ao focalizar Subespaço Central pode-se observar que em 1940, além de Belo Horizonte e Nova Lima,predominam asarticulações ferroviárias e a proeminência dos municípios da porção sul em termos de desempenhoeconômica (aindasob forte influência do Distrito Federal). Já no ano 2010 as rodoviassobrepujam amplamente as ferrovias, e o efeito da metropolização de Belo Horizonte fica muito evidente. Destacam-se Ouro Preto, Itabira e Sete Lagoas, pela presença da mineração, e Divinópolis, por sua produção têxtil, metalúrgica, siderúrgica, e pela sua articulação entre a Região Central e o Triângulo Mineiro. Queiroz (2013) aponta que atualmente a Região Metropolitana de Belo Horizonte (RMBH) exerce forte grau de especialização no setor metalomecânico, resultante da proximidade de fontes de recursos naturais. Matos (1994) acrescenta que os municípios do entorno de Belo Horizonte, tais como Betim e Contagem, tornaram-se também populosos e economicamente relevantes dada sua próspera infraestrutura urbano-industrial e o alto valor da terra urbanapela proximidade da capital mineira.

O Subespaço de Análise Oeste (Figura 4) evidencia já em 1940 a importância populacional e produtiva do cluster Uberlândia-Uberaba-Araguari, com maior expressão, secundados por Araxá. As articulações viárias na região eram realizadas predominantemente por estradas de ferro que articulavam a região com Belo Horizonte e São Paulo. À época suas porções norte e extremo oeste não dispunham de municípios com dinamismo significativo. O cenário em 2010 é bastante diverso: o fortalecimento de seu perfil agroindustrial, a polarização por Brasília e os maciços investimentos em infraestrutura permitiram a formação de uma importante e bem distribuídarede de cidades. As frações de baixo dinamismo observadas em 1940 ganham expressão em 2010. Os municípios de Unaí e Paracatu (norte), em função dos programas de desenvolvimento do cerrado, e Ituiutaba (oeste), em decorrência do desenvolvimento da pecuária o que a tornou entreposto comercial estrategicamente localizado entre Uberlândia e o Centro-Oeste brasileiro. Umaextensa rede rodoviária foi implantada, e a rede ferroviária se expandiu para a porção norte do triângulo, se adentrando no Estado de Goiás, além de vertebrar cidades médias relevantes como Patos de Minas e Patrocínio. Para Queiroz (2013), é essa a rede urbana mineira que possui as melhores condições de vida e infraestrutura urbana, com homogeneidade entre seus espaços microrregionais.

${ }_{28}$ Considerou-se aqui, além das ferrovias, o traçado das rodovias nacionais, por serem consideradas aquelas de maior relevância e tráfego. 
No Subespaço de Análise Sul (Figura 5) observa-se em 1940 um conjunto de centralidades de produção tradicional interligadas por ferrovia, sem qualquer município classificado nos dois grupos mais produtivos. Nessa época, a região estava em decadência, mas já começava a receber benefíciosda polarização paulista. Nos anos de 1970 apresentou um surto de crescimento industrial, recebendo dividendos da desconcentração da indústria paulista por oferecer infraestrutura com grande capacidade de geração de energia, rede viária bem articulada (incluindo a rodovia Fernão Dias) e a proximidade de grandes mercados consumidores (QUEIROZ, 2013). Em 2010 é notável a presença de várias cidades médias bem articuladas, enquanto as cidades-destaque em 1940 permanecem relevantes, acrescidas de duas novas (Alfenas e Três Corações), com ganhos de posição em termos econômicos entre os municípios-destaque.

A Figura 6 traz o Subespaço de Análise Leste. Em 1940 esse subespaço concentrava a maior parte dos municípios-destaque mineiros, localizados em sua porção sul, beneficiados pela proximidade com o Rio de Janeiro, e polarizados por Juiz de Fora, que possuía para os padrões da época elevada produção industrial. Ali se observam dois clusters de municípios, o mais importante contendo Juiz de Fora, Santos Dumont, Barbacena, São João Del Rey e Lavras (os três últimos do S.A. Central), e o segundo formado por Além Paraíba, Leopoldina, Cataguases, Ubá e Muriaé, ambos articulados por redes ferroviárias. Na porção norte deste Subespaço verifica-se a baixa dinamização da Zona da Mata, ainda em processo de ocupação.

Já em 2010 verifica-se uma significativa mudança de cenário: parte dos municípios da porção sul deixa de se destacar no contexto mineiro, e outros, na porção norte, ganham força. A mineração, a siderurgia e a silvicultura viabilizam a criação e expansão do Vale do Aço (onde se ressalta a articulação possibilitada pela Estrada de Ferro Vitória a Minas), capitaneado por Ipatinga. Governador Valadares torna-se importante polo regional de serviços, muito bem articulado pela BR-116 (Rodovia Rio-Bahia). Apesar das perdas no ritmo de crescimento das cidades vizinhas e da desarticulação da rede ferroviária local, Queiroz (2013) observa que Juiz de Fora se mantém como importante centralidade populacional e produtiva, com menor dependência do Rio de Janeiro e articulações significativas com Belo Horizonte e São Paulo resultante de fortes investimentos no setor industrial e modernização do setor de serviços.

Por fim, o Subespaço de Análise Norte apresentava em 1940 quatro municípios-destaque, todos eles servidos por estradas de ferro: Montes Claros e Diamantina conectados à porção central do Estado, e Araçuaí e Teófilo Otoni ao litoral do Espírito Santo. À época, Diamantina e Araçuaí ainda colhiam os últimos frutos de um rico período de mineração e produção têxtil que atravessou os séculos XVIII e XIX. Nasegunda metade do século XX passaram a conviver com a estagnação. 
Em 2010, Montes Claros e Teófilo Otoni mantêm-se como municípios-destaque, o primeiro por se tornar o mais importante entreposto comercial do norte de Minas, com conexões rodoviárias em todas as direções e um eixo ferroviário que articula a região central mineira com Salvador (BA). Teófilo Otoni, por sua vez permanece como município centralizador de serviços nos vales do Jequitinhonha e Mucuri, além de desenvolver atividade mineradora e de lapidação de pedras preciosas, entretanto, deixa de ser servido por estrada de ferro. Além destes, em 2010 destacam-se na região os municípios de Janaúba - na produção pecuária - e Pirapora, na metalurgia, siderurgia, têxteis, fruticultura e no setor de serviços.

A análise dos dados sobre população e produção revelou a mudança do perfil produtivo de Minas Gerais. Aprodução industrial, menos importante em 1940, superou com folga a produção agropecuária em 2010 acompanhada pelofortalecimento do setor de serviços. Apesar disso, 69,3\% dos 853 municípios mineiros em 2010 ainda possuíam o setor primário mais vigoroso que o secundário, alguns em razão do desenvolvimento da agroindústria, outros em decorrência do próprio atraso econômico. O conjunto de dados indica, também, que ao longo dos setenta anos analisados, a população e a produção se concentraram nos médios e grandes municípios, fenômeno fortemente influenciado pelas tendências econômicas ditadas por São Paulo e emergência de Brasília.

Para que essa mudança espacial dos rumos da economia mineira se materializasse, foi necessário um tremendo esforço político em prol da modernização e estruturação da base produtiva industrial, o que ocupou quase um século. Mesmo nos municípios-destaque eminentemente agrícolas, foram necessárias mudanças nos métodos de produção para que estes se mantivessem competitivos no mercado.

A Figura 8 traz o conjunto de municípios-destaque em Minas Gerais em 1940 e 2010 segundo a relação entre o setor primário e secundário em termos de PIB. Confirma-se a primazia do setor primário sobre o secundário em 1940 na maior parte dos municípios-destaque mineiros (as exceções são: Belo Horizonte, Ouro Preto, Mariana, Nova Lima, Santa Bárbara, São João Del Rey, Santos Dumont, Juiz de Fora e Itajubá), provavelmente porque até então o dinamismo econômico no Estado ainda dependia muito dosganhos da mineração e de uma indústria de base a ela associada, além da indústria têxtil. Nesse período, Minas ainda cumpria um papel secundário na economia brasileira, como fornecedor de insumos a São Paulo e Rio de Janeiro.

Já em 2010, além da expressiva mudança na distribuição territorial dos municípios-destaque -emdecorrência do surgimento de redes geográficas influenciadas pelos efeitos das polarizações verificadas ao longo dos setenta anos analisados -, verificou-se que es- 
ses municípios desenvolveram fortemente o setor secundário, muito mais que o setor primário. Aqueles onde não se verificou esse status - Esmeraldas, Curvelo, Patrocínio, Unaí e Janaúba - a produção agrícola e pecuária é marcante, mas baseadas em técnicas modernas que permitem alta produtividade,que tornam esse setor competitivo nacionalmente.

Figura 3: Subespaço de Análise Central - Municípios-destaque em 1940 e 2010 segundo seu Produto Interno Bruto (R\$ 1.000,00, a preços constantes corrigidos para 0 ano 2000).
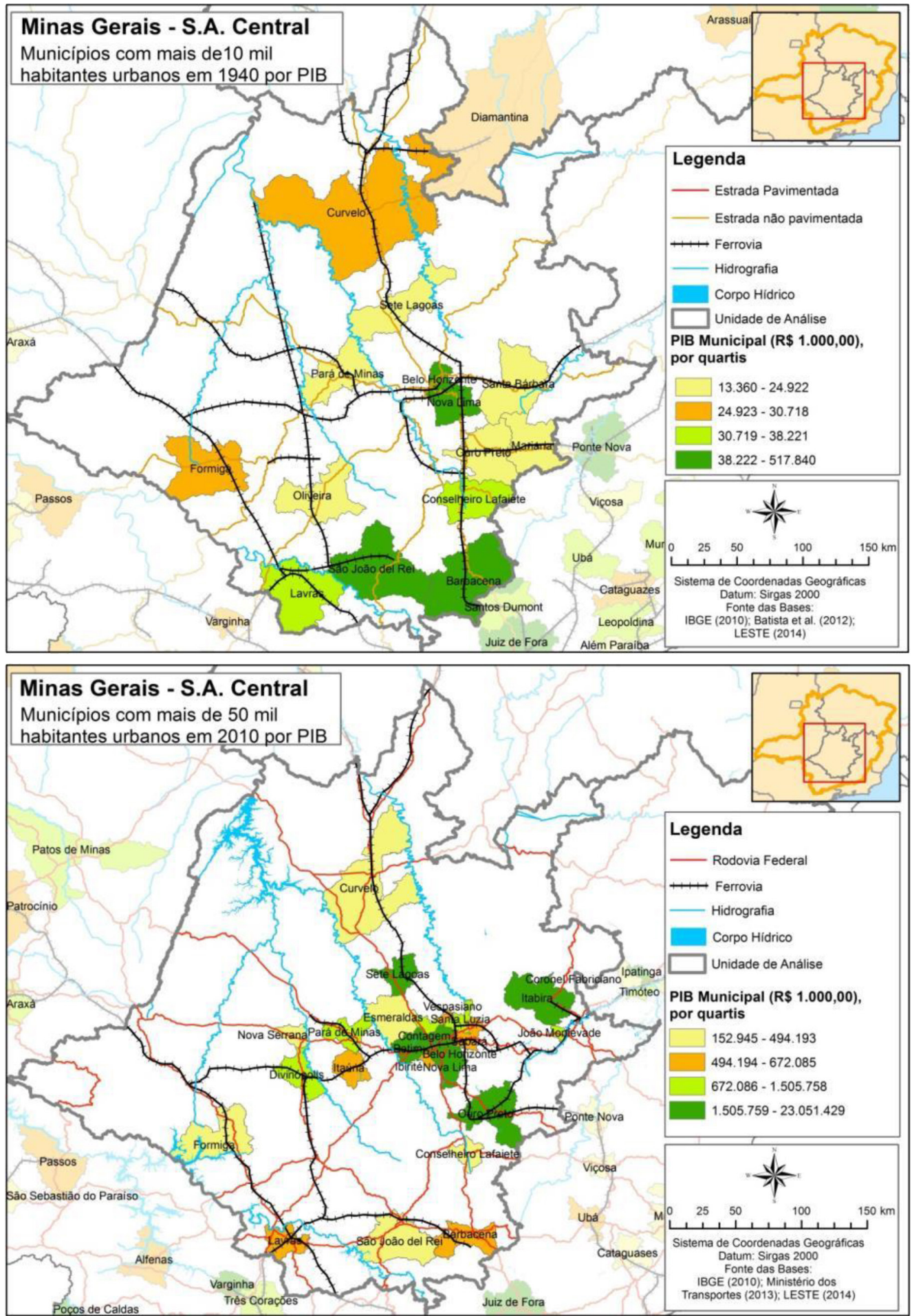
Figura 4: Subespaço de Análise Oeste - Municípios-destaque em 1940 e 2010 segundo seu Produto Interno Bruto (R\$ 1.000,00, a preços constantes corrigidos para 0 ano 2000).
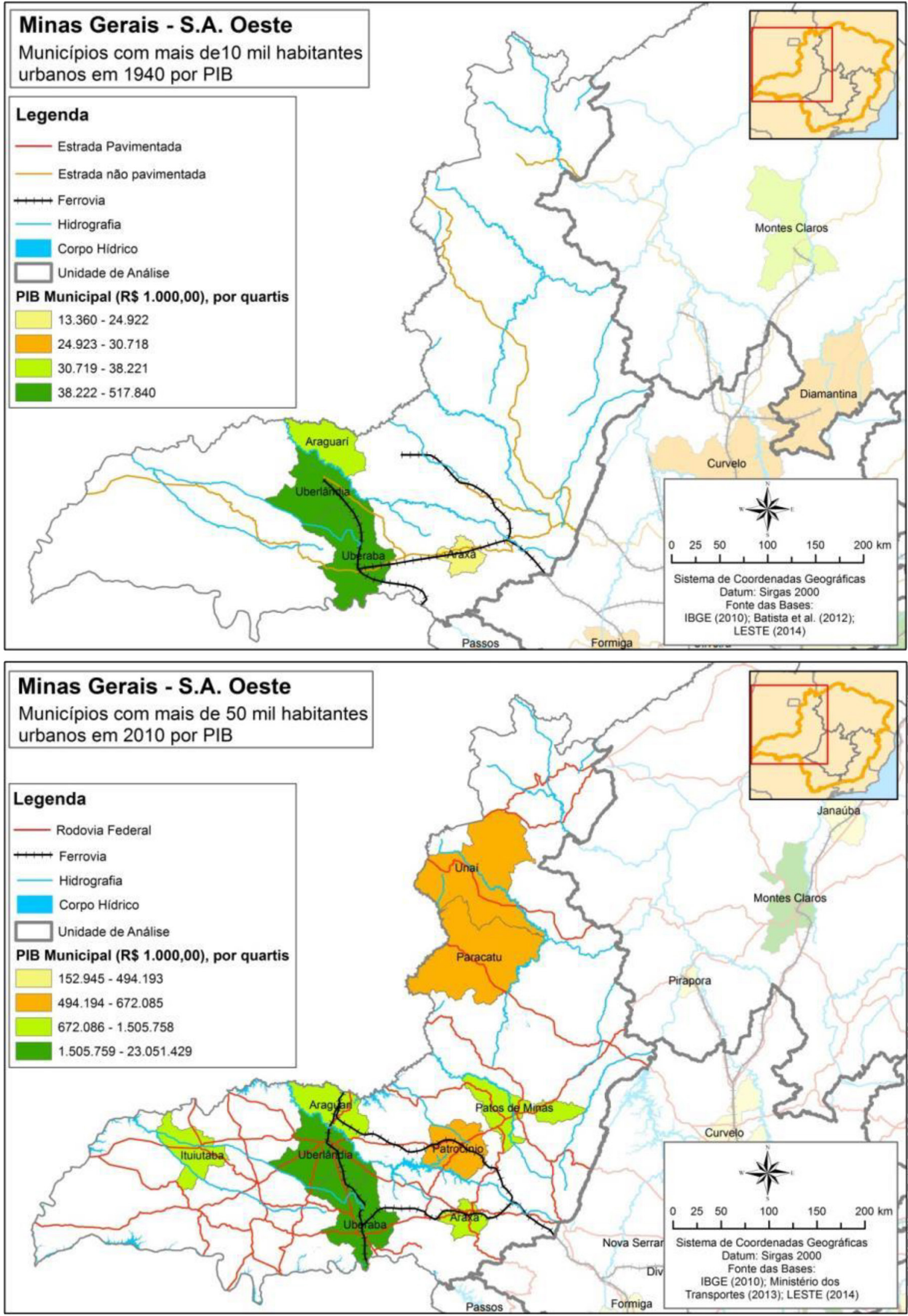
Figura 5: Subespaço de Análise Sul - Municípios-destaque em 1940 e 2010 segundo seu Produto Interno Bruto (R\$ 1.000,00, a preços constantes corrigidos para o ano 2000).
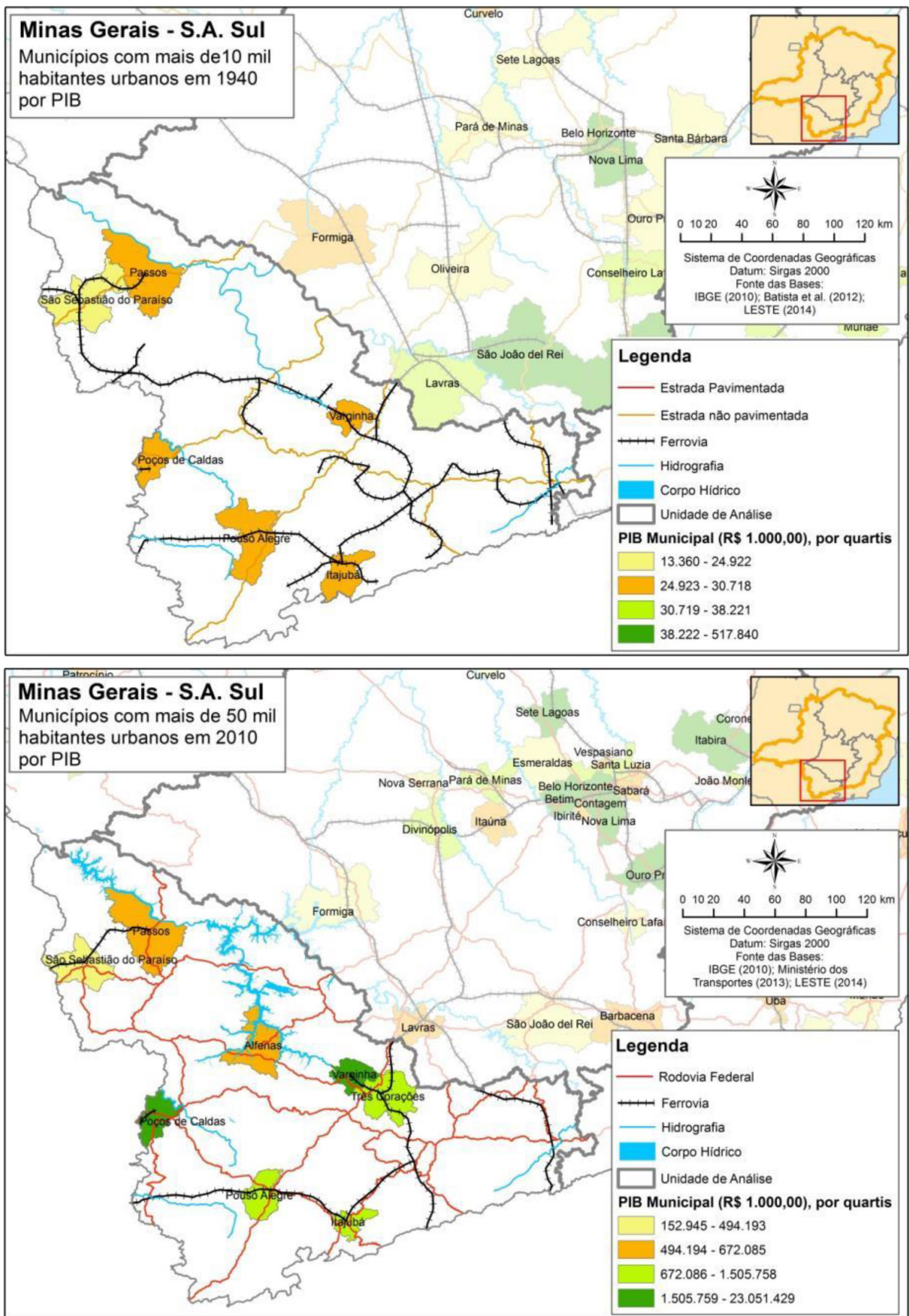
Figura 6: Subespaço de Análise Leste - Municípios-destaque em 1940 e 2010 segundo seu Produto Interno Bruto (R\$ 1.000,00, a preços constantes corrigidos para o ano 2000).
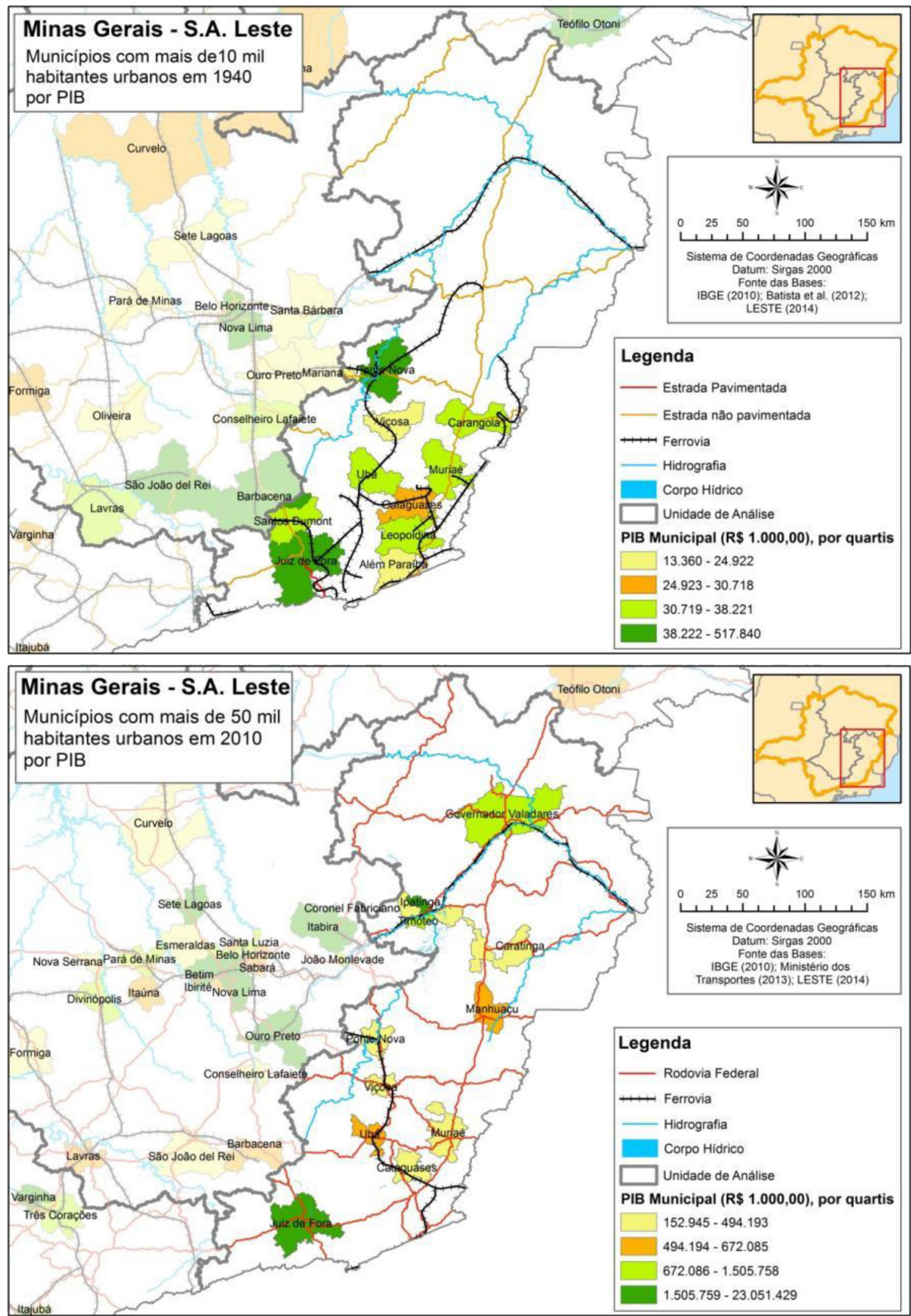
Figura 7: Subespaço de Análise Norte - Municípios-destaque em 1940 e 2010 segundo seu Produto Interno Bruto (R\$ 1.000,00, a preços constantes corrigidos para o ano 2000).

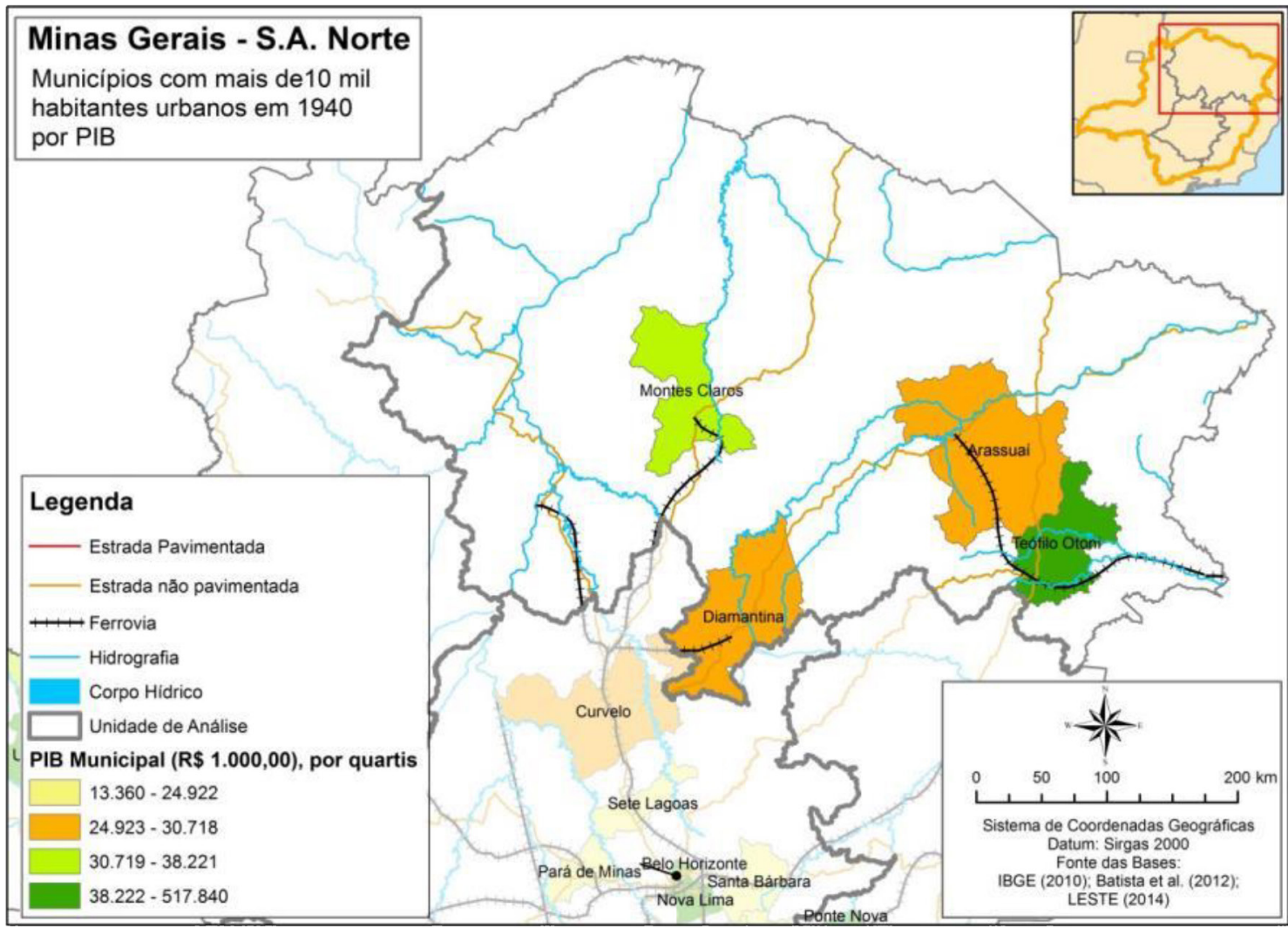

() $x$

or $\stackrel{\infty}{\bullet}$

0

อ. จ่

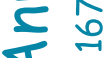

$\checkmark z$

0

$\frac{0}{4}$

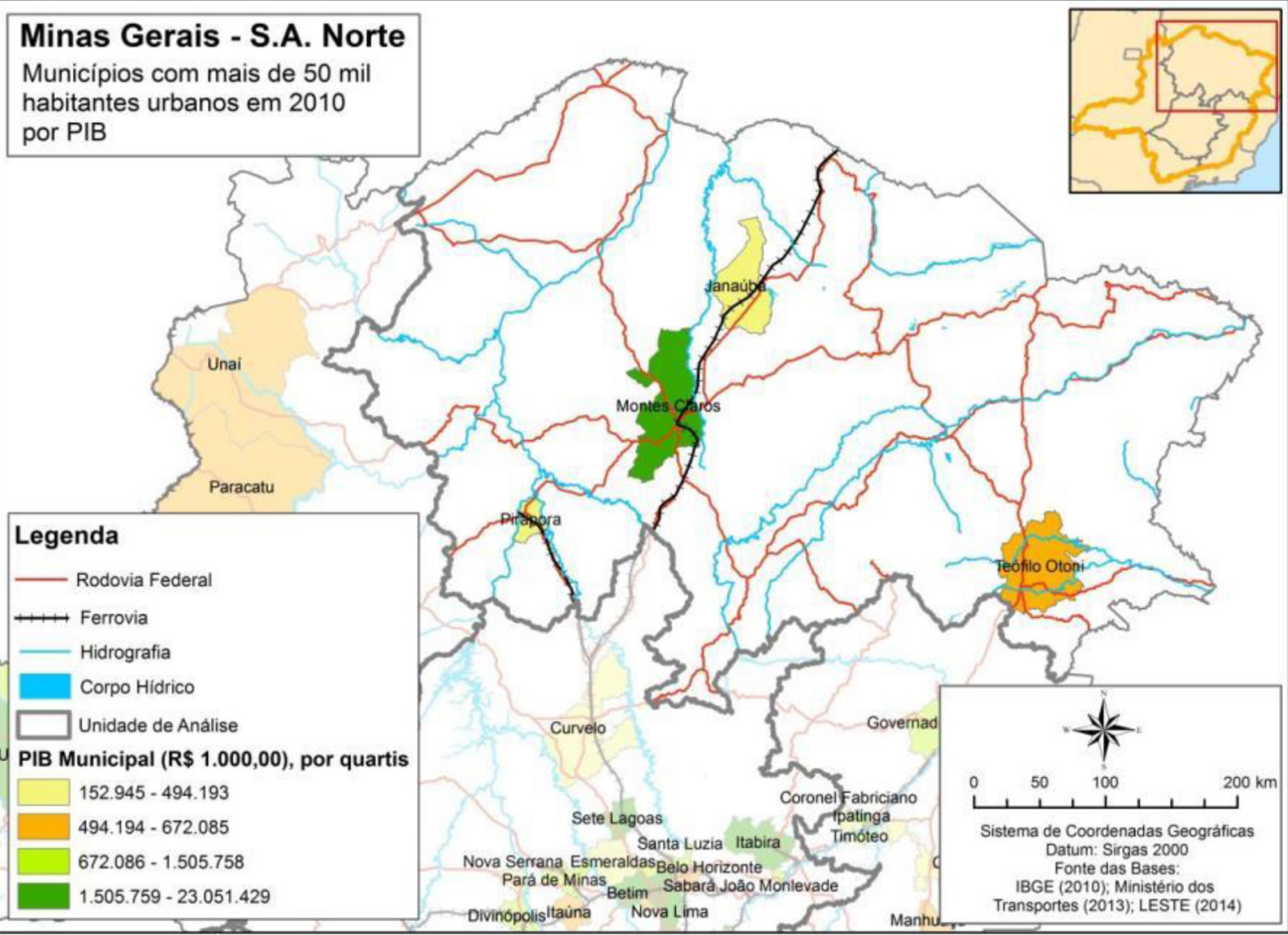

a

O 
Figura 8: Municípios-destaque em Minas Gerais em 1940 e 2010 segundo a relação entre o setor primário e secundário do Produto Interno Bruto
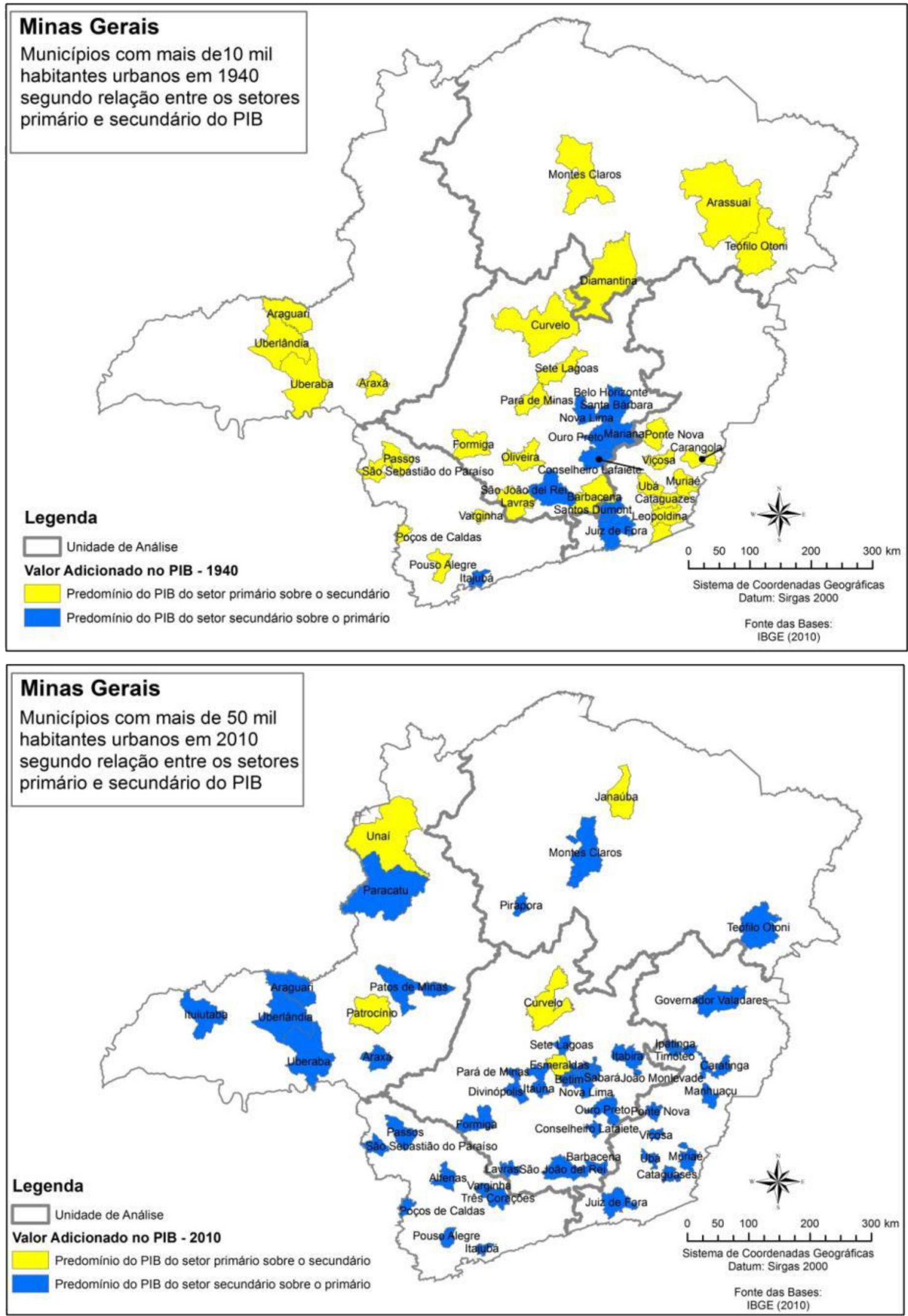


\section{CONSIDERAÇÕES FINAIS}

Ao longo das análises apresentadas, ficou evidente que Minas Gerais experimentouem sua história dois períodos de forte modernização. Oprimeiro,muito conhecido foi o do Ciclo do Ouro, iniciado em fins do século XVII. Osegundo, menos conhecido, resultou da conjugação dos esforços políticos em prol de sua industrialização, que se valeuda desconcentração industrial paulista e do interesse do capital internacional na segunda metade do século XX. No primeiro caso, as riquezas geradas pelo ouro e a vontade de se desenvolver o território nos moldes europeus permitiram que Minas convivesse com um precoce processo de modernização. No segundo caso, a singularidade advém dos esforços de sua elite políticaem prol da industrialização, iniciadoem fins do século XIX, com a pela aplicação de diversas estratégias estruturadoras que tiveram sucesso (ainda que tardio).

As mudanças modernizadoras mais intensas foram verificadas principalmente nos municípios que já representavam centralidades históricas, mas também em outros, cujas polarizações decorrentes dos processos de reestruturação assistidos no período analisado permitiram que se tornassem importantes entrepostos comerciais, capazes de atrair população e centralizar serviços de toda ordem. O crescimento de São Paulo, a fundação de Brasília, a criação do parque siderúrgico do Vale do Aço e a metropolização de Belo Horizonte foram os principais balizadores destas polarizações.

Ficaram evidentes também os laços entre a modernização da indústria mineira e a concentração urbano-econômica. Aqueles municípios que foram alvo específico de estruturações planejadas pelo Estado - sobretudo os que já representavam centralidades -, ou que foram capazes de lançar suas próprias bases para a industrialização (seja via fornecimento de infraestrutura básica, incentivos fiscais e/ou locacionais) foram capazes de atrair investidores e mão-de-obra, e por consequência desenvolver um setor terciário vigoroso. Mais recentemente, há a focalização por parte das estratégias governamentais de formar mão de obra especializada nestes municípios via instalação de universidades e escolas técnicas por todo o Estado, o que reforça a importância desses centros e beneficia tanto os investidores já instalados quanto aqueles em busca de novas oportunidades.

Minas permanece muitas: se em termos relativos a produção industrial superou a agropecuária, em termos absolutos, dois terços dos municípios ainda têm predominância do setor primário sobre o secundário. Mas Minas são outras, pois, pelo menos em seus municípios-destaque, conseguiu se desvincular de um destino predominantemente agropecuário tradicional que vinha sendo traçado até 1940, e desenvolveu seu setor industrial. Territorialmente, verificou-se em 2010 distribuição mais homogênea dos municí- 
pios-destaque em relação a 1940, o que indica melhor articulação econômica e fortalecimento da rede urbana mineira.

Para além dos diversos fatores que permitiram a reestruturação modernizadora da sua economia, há que se destacar a importância da vontade mineira nos campos político e econômico em prol do desenvolvimento do Estado, por meio de iniciativas das mais diversas sem as quais provavelmente não se teria vencido a primazia do setor primário que o destino lhe tinha reservado.

\section{REFERÊNCIAS BIBLIOGRÁFICAS}

1. ALONSO, J. A. F. Efeitos da reestruturação produtiva na dinâmica da Região Metropolitana de Porto Alegre (RMPA) na década de 90. Cadernos Metrópole. ISSN (impresso) 1517-2422; (eletrônico) 2236-9996, n. 11, 2004.

2. ANDRADE, T. A.; SERRA, R. V.. As cidades médias e o processo de desconcentração espacial das atividades econômicas no Brasil: 1990/95. Anais: Encontros Nacionais da ANPUR, v. $8,2013$.

3. AZZONI, C. R.. Sobre a necessidade da política regional. Unidade e fragmentação: a questão regional no Brasil. São Paulo: Perspectiva, 2002.

4. BAENINGER, R.. Deslocamentos populacionais, urbanização e regionalização. Revista Brasileira de Estudos de População, v. 15, n. 2, p. 67-81, 2014.

5. BATISTA, F. A.; BARBOSA, L. S.; GODOY, M. M.. Transportes, modernização e formação regional-Subsídios a história da era ferroviária em Minas Gerais, 1870-1940. DOI: 10.5212/Rev. Hist. Reg. v. 17i1. 0007. Revista de História Regional, v. 17, n. 1, 2012.

6. BECKER, B. K.; EGLER, C. A. G..Brasil: uma nova potência regional na economia-mundo. Bertrand Brasil, 1993.

7. BECKER, B. K.. Tendências de transformação do território no Brasil: vetores e circuitos. Revista território, v. 1, n. 2, p. 5-17, 1997.

8. BERTELLI, F.. Espacialização das Indústrias em Minas Gerais: os arranjos produtivos locais e sua relação com os movimentos populacionais. Dissertação de Mestrado. IGC/UFMG. 2014. (No prelo).

9. CANO, W.. Concentração e desconcentração econômica regional no Brasil: 1970/95. Economia e sociedade, v. 8, p. 101-141, 1997.

10. CANO, Wilson. Padrões diferenciados das principais regiões cafeeiras In: . Ensaios sobre a formação econômica regional do Brasil.Campinas: Editora da Unicamp, 2002.

11. DINIZ, C. C.. Estado e capital estrangeiro na industrialização mineira. UFMG/PROED, 1981. 
12. DINIZ, C. C.; CROCCO, M. A.. Reestruturação econômica e impacto regional: o novo mapa da indústria brasileira. Nova economia, v. 6, n. 1, p. 77-103, 1996.

13. DULCI, O. S.. Política e recuperação econômica em Minas Gerais. Editora UFMG, 1999.

14. ESPINDOLA, H. S.. Modernização, dinâmica territorial e mudanças ambientais. In: Gilvan Ramalho Guedes; Ricardo Ojima. (Org.). Território, Mobilidade Populacional e Ambiente. 1ed. Governador Valadares: Editora Univale, 2012, v. 1, p. 157-200.

15. FERREIRA, R. N.; MATOS, R. E. S.. Migração de trabalhadores no mercado formal brasileiro entre 1995 e 2003 e as tendências da reestruturação territorial. Encontro Nacional de Estudos Populacionais, v. 14, 2004.

16. FERREIRA, A. A Cidade no Século XXI: Segregação e Banalização do Espaço. 2. Ed. Rio de Janeiro: Consequência, 2013. V. 1. 324p.

17. GARCIA, R. A.. Modernização e crescimento populacional nos municípios de Minas Gerais: uma aplicação do método"Grade ofMembership". Seminário Sobre a Economia Mineira, IX. Diamantina: Cedeplar/UFMG, 2000.

18. GODOY, M. M.; BARBOSA, D. H. D.; BARBOSA, L. S.. Da arte de conhecer as doenças: o Diagnóstico da Economia Mineira de 1968. Nova Economia, p. 343-388, 2010.

19. GOMES, M. T. S.. O debate sobre a reestruturação produtiva no Brasil. Raega-O Espaço Geográfico em Análise, v. 21, 2011.

20. IBGE. Evolução da Divisão Territorial do Brasil 1872-2010. Rio de Janeiro. 2011.

21. IPEADATA. Produto Interno Bruto dos Municípios IBGE - 1900/2013. Disponível em http:// www.ipeadata.gov.br/, acessado em 30/06/2015.

22. LESTE/UFMG. Atlas Viário de Minas Gerais. Belo Horizonte, 2014. (No prelo)

23. LENCIONI, S.. Reestruturação: uma noção fundamental para o estudo das transformações e dinâmicas metropolitanas. VI Encontro de Geógrafos da América Latina, 1998.

24. MATOS, R. E. S.. A desconcentração populacional em Minas Gerais e as mudanças na Região-Core. Encontro Nacional de Estudos Populacionais, v. 9, p. 457-472, 1994.

25. MATOS, R. E. S.. Aglomerações urbanas, rede de cidades e desconcentração demográfica no Brasil. Encontro Nacional de Estudos Populacionais, v. 12, 2000.

26. MATOS, R. E. S.; SANTOS, R.; COSTA, A.. O São Francisco das Lavras e do Sertão Mineiro e sua Influência na Origem de Minas Gerais. Cadernos do Leste, v. 8, p. 3-30, 2006.

27. MATOS, R. E. S.. A discussão do antiurbanismo no Brasil colonial. Geografias (UFMG), v. 7, n. 2, p. 40-55, 2011.

28. MATOS, R. E. S.. Trajetórias de contato nas humanidades; do espaço representado às conexões entre homens e lugares. 2012. 127 p. (Memorial Acadêmico).

29. MATOS, R. E. S.. Questões teóricas acerca dos processos de concentração e desconcentração da população no espaço. Revista brasileira de estudos de população, v. 12, n. 1/2, p. 35-58, 2014.

30. MINISTÉRIO DOS TRANSPORTES. Mapa Ferroviário. 2012. 
31. NEGRI, B.. Concentração e desconcentração industrial em São Paulo (1880-1990). Unicamp, 1996.

32. OLIVEIRA, F. J. G.. Desenvolvimento Local e Território em Tempos de Reestruturação Econômica: de que desenvolvimento e de que escala estamos falando?. Anais: Encontros Nacionais da ANPUR, v. 12, 2007.

33. PACHECO, C. A.. Desconcentração econômica e fragmentação da economia nacional. Economia e sociedade, v. 6, p. 113-140, 1996.

34. PEREIRA, R. C.. Estado, território e reestruturação produtiva na metrópole fluminense. Espaço e Economia. Revista brasileira de geografia econômica, n. 3, 2013.

35. PERROUX, F. Note surlanotion de pôle de croissance. EconomieAppliquée, 1955. In SCHWARTZMAN, Jacques.Economia Regional: textos escolhidos. CEDEPLAR, Belo Horizonte, 1977.

36. PIQUET, R.. Indústria e Território no Brasil Contemporâneo. Editora Garamond. Rio de Janeiro/RJ, 2007.

37. QUEIROZ, B. L.; BRAGA, T. M.. Hierarquia urbana em um contexto de desconcentração econômica e fragmentação do território: questionamentos a partir do caso da rede de cidades mineira. Anais: Encontros Nacionais da ANPUR, v. 8, 2013.

38. SABOIA, J.. A continuidade do processo de desconcentração regional da indústria brasileira nos anos 2000. Nova Economia, v. 23, n. 2, p. 219-278, 2013.

39. SOJA, E. W.. Geografias Pós-modernas: a reafirmação do espaço na teoria social crítica. Rio de Janeiro: Jorge Zahar, 1993.

40. TAVARES, H. M.. Reestruturação econômica e as novas funções dos espaços metropolitanos. Clacso, 2000.

41. VAINER, C. B.. Planejamento territorial e projeto nacional: os desafios da fragmentação. Revista Brasileira de Estudos Urbanos e Regionais, v. 9, n. 1, p. 9-23, 2011.

42. VALLE, M. H. F.; COSTA, A.; MATOS, R. E. S.. Nexos de associação entre urbanização, crescimento econômico e qualidade de vida em Minas Gerais entre 2000 e 2010. In: Seminário sobre a Economia Mineira, XVI.Diamantina: Cedeplar/UFMG, 2014.

Artigo recebido em 13 de julho de 2015.

Artigo aceito em 19 de agosto de 2015. 